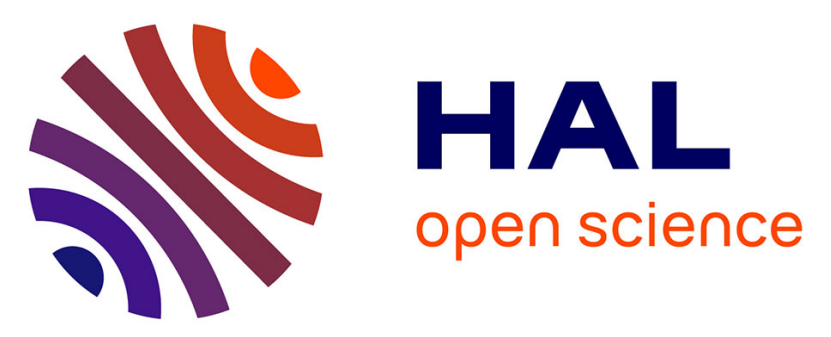

\title{
The challenging application of cosmogenic dating methods in residual glacial landforms: The case of Sierra Nevada (Spain)
}

David Palacios, Antonio Gómez-Ortiz, Jesús Alcalá-Reygosa, Nuria Andrés, Marc Oliva, Luis Tanarro, Ferran Salvador-Franch, Irene Schimmelpfennig, José M. Fernández-Fernández, Laëtitia Leanni

\section{To cite this version:}

David Palacios, Antonio Gómez-Ortiz, Jesús Alcalá-Reygosa, Nuria Andrés, Marc Oliva, et al.. The challenging application of cosmogenic dating methods in residual glacial landforms: The case of Sierra Nevada (Spain). Geomorphology, 2019, 325, pp.103 - 118. 10.1016/j.geomorph.2018.10.006 . hal01906554

\section{HAL Id: hal-01906554 \\ https://hal.science/hal-01906554}

Submitted on 27 Nov 2020

HAL is a multi-disciplinary open access archive for the deposit and dissemination of scientific research documents, whether they are published or not. The documents may come from teaching and research institutions in France or abroad, or from public or private research centers.
L'archive ouverte pluridisciplinaire HAL, est destinée au dépôt et à la diffusion de documents scientifiques de niveau recherche, publiés ou non, émanant des établissements d'enseignement et de recherche français ou étrangers, des laboratoires publics ou privés. 
1 The challenging application of cosmogenic dating methods in residual glacial landforms: the case of Sierra Nevada (Spain)

4 David Palacios $^{\mathrm{a}}$, Antonio Gómez-Ortiz ${ }^{\mathrm{b}}$, Jesús Alcalá-Reygosa ${ }^{\mathrm{c}}$, Nuria Andrés ${ }^{\mathrm{a}}$, Marc Oliva ${ }^{\mathrm{b}}$,

5 Luis M. Tanarro ${ }^{\mathrm{a}}$, Ferran Salvador-Franch ${ }^{\mathrm{b}}$, Irene Schimmelpfennig ${ }^{\mathrm{d}}$, José M. Fernández6 Fernández ${ }^{\mathrm{a}}$, Laëtitia Léanni ${ }^{\mathrm{d}}$, ASTER Team ${ }^{\text {de }}$

7

${ }^{\text {a }}$ Department of Geography, Universidad Complutense de Madrid, Madrid, Spain

${ }^{\mathrm{b}}$ Department of Geography, Universitat de Barcelona, Barcelona, Spain

${ }^{\mathrm{c}}$ Facultad de Filosofía y Letras, Universidad Nacional Autónoma de México, Ciudad de México, Mexico

${ }^{\mathrm{d}}$ Aix-Marseille Université, CNRS, IRD, Coll. France, UM 34 CEREGE, Aix-en-Provence, France

${ }^{\mathrm{e}}$ Consortium: Georges Aumaître, Didier Bourlès, Karim Keddadouche

Corresponding author: davidp@ucm.es (D. Palacios)

\section{Abstract}

An accurate review of the literature on surface exposure dating methods shows evidence of the difficulty in applying cosmogenic dating methods to old moraines because of the intensity of Late Quaternary erosion processes. Moreover, as in some previous cases, we found also special difficulties in applying these methods to LIA moraines, due to the intensity of current paraglacial processes. The objective of this study is to apply cosmogenic dating methods to very old and very young moraines, which in both cases have been or are being affected intensively by erosion. With this purpose, we collected samples of boulders from moraines corresponding to: (a) the penultimate glaciation, and (b) the Little Ice Age (LIA), both from Sierra Nevada, in the south of the Iberian Peninsula. The sampling strategy was based on a preliminary accurate analysis of the geomorphological settings of two valley sites that 
resulted in the collection of only four boulder samples from an old moraine and three more from a very recent moraine. Using in situ produced cosmogenic ${ }^{10} \mathrm{Be}$ to date these boulders, the old samples yielded an age of ca. 130-135 ka for moraine stabilization. The younger samples indicate that the LIA moraine accretion probably occurred between the $14^{\text {th }}$ and $17^{\text {th }}$ centuries, with a subsequent stage of accumulation during the $19^{\text {th }}$ century as suggested by historical documents. Both, dating a glaciation that occurred prior to the last Pleistocene glacial cycle and dating LIA glacial stages are novel in the context of Iberian glaciations and agree with other palaeoenvironmental studies in Iberian and in other European mountains. The limited number of boulders adequate for cosmic-ray exposure dating prevents statistical methods to be applied, and therefore highlights the need to improve geomorphological criteria in sample selection.

Key words: Sierra Nevada, cosmic-ray exposure dating, beryllium 10, Little Ice Age, Penultimate Glacial Cycle.

\section{Introduction}

Scientific knowledge on the glacial evolution of the Iberian mountains has greatly advanced over the last decade based on the application of Cosmic-Ray Exposure (CRE) dating on moraines, erratic boulders and polished surfaces. This method allowed inferring spatiotemporal patterns of glaciation since the maximum extent of glaciers during the last Pleistocene glacial cycle, with a focus on the Last Glacial Maximum (LGM) (García-Ruiz et al., 2010), Oldest Dryas (Palacios et al., 2017a) and Younger Dryas (García-Ruiz et al., 2016) in the main Iberian ranges such as the Cantabrian Mountains (Rodríguez-Rodríguez et al., 2016), Pyrenees (Delmas, 2015), Central System (Domínguez-Villar et al., 2013), Iberian System (Fernández-Fernández et al., 2017) and Sierra Nevada (Palacios et al., 2016). 
The existence and distribution of landforms and deposits, their delimitation and mapping, generated by glacial advances prior to the last Pleistocene glaciation are known since the first geomorphological descriptions carried out in most Iberian mountains in the late $19^{\text {th }}$ and early $20^{\text {th }}$ centuries, such as in the Pyrenees (Penck, 1883; Nussbaum, 1949, Barrère, 1953), Cantabrian Mountains (Penck, 1897; Obermaier, 1914), Central System (Penck, 1897; Obermaier and Carandell, 1917) and Sierra Nevada (Quelle, 1908; Obermaier, 1916).

However, the present knowledge on calendar of development of these landforms is scarce, and it is based on CRE dating only in very few cases. In fact, the only CRE data related to the penultimate glacial cycle were obtained with ${ }^{21} \mathrm{Ne}$ in the NW of the Iberian Peninsula (VidalRomaní, et al., 2015). These authors found glacial evidence (moraine boulders and polished surfaces) of a maximum advance that occurred at $155 \pm 30 \mathrm{ka}{ }^{21} \mathrm{Ne}$ age in the Serra de Queixa, whereas polished bedrock surfaces were dated at $231 \pm 48 \mathrm{ka}$ and $131 \pm 31 \mathrm{ka}{ }^{21} \mathrm{Ne}$ ages in the Serra da Geres. In addition, erratic blocks were dated at $113.9 \pm 7.1 \mathrm{ka}{ }^{10} \mathrm{Be}$ age in the Porma Valley, Cantabrian Mountains (Rodríguez-Rodríguez et al, 2016). Another erratic boulder, with a minimum ${ }^{10} \mathrm{Be}$ age of $122.2 \pm 4.9 \mathrm{ka}$ was found in Ariège valley (northern Pyrenees) (Delmas et al., 2011). This scarcity of CRE data from old moraines may be due to the problem of moraine degradation after being affected by intensive erosion, as it has been observed even in younger moraines of other regions (Putkonen and Swanson, 2003; Briner et al., 2005; Putkonen et al., 2008; Balco, 2011; Heyman et al., 2011).

The rest of dates corresponding to glacial landforms formed during the penultimate glaciation in the Iberian Peninsula were carried out by other dating methods. Villa et al. (2013) were able to date with $U$ / Th the limestone of cemented calcareous breccia in Duje valley, Picos de Europa, also in the Cantabrian Mountains. This breccia deposit lies on glacially abraded surfaces and is covered by moraines dated between $394 \pm 50 \mathrm{ka}$ and $276 \pm 23 \mathrm{ka} / 394 \pm 50 \mathrm{ka}$ U / Th age. In the southern slope of the Central Pyrenees, Optically Stimulated Luminescence 
(OSL) dating was applied to sandy layers in fluvioglacial terraces in two nearby valleys that show the following ages: $151 \pm 11 \mathrm{ka}$ in the Gállego valley (Lewis et al., 2009) and $263 \pm 21$ ka and $171 \pm 22$ ka in the Aragón valley (García-Ruiz et al., 2013).

In other Mediterranean mountains, landforms originated from glaciations prior to the Late Pleistocene Glaciation (LPG) have been dated by U / Th, ${ }^{230} \mathrm{Th}$ and OSL methods in the Balkan region (Hughes et al., 2006a, 2006b, 2007), Dinaric Alps (Hughes et al., 2011) and Apennines (Kotarba et al., 2001), but not through CRE dating. In comparison to the large dataset of CRE ages existing for reconstructing the LPG in the Alps, there are only a few erratic boulders related to the penultimate glacial cycle dated by this method (Graf et al., 2015), as it is also the case of the Himalayas (Schaefer et al., 2008). On the contrary, the application of ${ }^{230} \mathrm{Th}$-dates on the stalagmite record in the Alps allowed determining with high resolution the last maximum ice advance of the penultimate glacial cycle at $133.1 \pm 0.7$ and $131.9 \pm 0.6 \mathrm{ka}$. These dates coincide with Heinrich stadial 11 and the onset of the penultimate deglaciation or Termination II (TII) which started at 131.8 $\pm 0.6 \mathrm{ka}$ (Häuselmann et al., 2015) and reached its maximum intensity at 130.9 $\pm 0.9 \mathrm{ka}$ (Moseley et al., 2015).

However, CRE methods have never been applied to date the Little Ice Age (LIA) in the Iberian Peninsula, although this cold event has been extensively documented in this region (González-Trueba et al., 2008; Oliva et al., 2018a). CRE dating showed that the LIA was the most extensive Holocene glacial advance in most Iberian mountains (Palacios et al., 2017b), with the exception of some cirques in the Central Pyrenees (García-Ruiz et al., 2014). In fact, after pioneer studies in New Zealand (Schaefer et al., 2009) and the Andes (Licciardi et al., 2009), the use of CRE dating methods to date landforms of Neoglacial and LIA age has just been recently applied in the Alps (Schimmelpfennig et al., 2012, 2014; Le Roy et al., 2017), Arctic (Jomelli et al., 2016; Young et al., 2015) and Central Asia mountains (Dong et al., 2017; Li et al., 2016). 
102 Radiocarbon dating on glacial, fluvioglacial and lacustrine sediments, as well as speleothems,

103 tree rings and historical documents established the onset of the LIA in the Iberian Peninsula at 1041300 common era (CE), with the coldest conditions of ca. $2^{\circ} \mathrm{C}$ below present-day values at 105 1620-1715 CE and the last cold episodes at 1760-1800 and 1815-1835 CE (Oliva et al., 106 2018a). In Sierra Nevada there were also small glaciers during the LIA that have been 107 reconstructed based on radiocarbon dating of lake sediments (Oliva and Gómez-Ortiz, 2012) 108 and through historical documents (Gómez-Ortiz et al., 2009, 2018).

109 The objective of this work is to apply CRE methods to glacial landforms originated during 110 advances prior to LPG and to very young moraines as well as to review and discuss those 111 found in this research in comparison to other similar studies. Sierra Nevada constitutes a 112 unique environment to examine the use of CRE dating as a potential tool to reconstruct the 113 chronology of old and young glaciations, due to the well-constrained glacial chronological 114 record of the LPG and the existence of glacial landforms originated before and after of this 115 glaciation in this mountains.

\section{Study area}

117 Sierra Nevada is located in the SE of the Iberian Peninsula and runs SW-NE parallel to the

118 Mediterranean Sea (Fig. 1). This massif includes the highest peaks of the Iberian Peninsula:

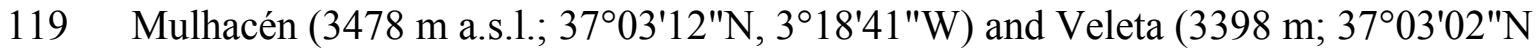

$\left.1203^{\circ} 20^{\prime} 54^{\prime \prime} \mathrm{W}\right)$. The area is composed of Paleozoic metamorphic rocks, mainly micaschists,

121 profoundly tectonized during the Alpine orogeny, with the presence of intensive foliation and 122 joints that makes them susceptible to intense weathering (Messerli, 1965; Sanz de Galdeano 123 and López-Garrido, 1999). Climate conditions in Sierra Nevada are characteristic of a semi124 arid mid-latitude mountain environment, with a Mean Annual Air Temperature (MAAT) at $1252500 \mathrm{~m}$ of $4.4{ }^{\circ} \mathrm{C}$ and a total precipitation of $710 \mathrm{~mm}, 40 \%$ of which as snow (Oliva et al., 
2016a). The MAAT at the top of the Veleta peak between 2002 and 2013 was $0.08{ }^{\circ} \mathrm{C}$, with a

127 slight increase of $0.12{ }^{\circ} \mathrm{C}$ along this period (Oliva et al., 2016a).

128 The Quaternary landscape evolution of Sierra Nevada has been largely studied over the last

129 decades (Fig. 1, Table 1). From the first basic geomorphological observations of the late $19^{\text {th }}$

130 and early $20^{\text {th }}$ centuries to the recent multi-dating approaches, our understanding of the glacial

131 processes shaping the landscape of the highest lands has significantly improved (i.e. Gómez-

132 Ortiz et al., 2015).

133 During the 1960s and 1970s several authors suggested the existence of older glaciations

134 occurred prior to the LPG, formerly known as the Riss glaciation in Alpine terminology.

135 Their observations focused on the existence of highly eroded moraine remnants and

136 fluvioglacial deposits at very low altitudes, mainly in the southern slope of the massif

137 (Hempel, 1960; Messerli, 1965; Lhenaff, 1977; Sánchez-Gómez, 1990). However, this

138 hypothesis has not been validated until now though direct dating methods.

139 By contrast, the LPG has been recently well-constrained with CRE techniques. Gómez-Ortiz

140 et al. (2012) and Palacios et al. (2016) reported two major glacial advances occurred at ca. 30-

$14132 \mathrm{ka}$ and 19-20 ka. The second stage of glacial advance occurred in phase to the global Last

142 Glacial Maximum and reached almost the same extent than during the previous glacial stage.

143 Subsequently, temperature increase recorded worldwide (Clark et al., 2009) favored a massive

144 deglaciation of the massif, although two stages of glacial expansion occurred during the

145 transition towards the Holocene, namely during the Oldest Dryas and Younger Dryas. During

146 these phases, glaciers expanded significantly and flowed down-valleys several kilometers,

147 both in southern and northern slopes (Gómez-Ortiz et al., 2012; Palacios et al., 2016).

148 The Holocene was characterized by warmer temperatures that promoted the gradual melting

149 of these glaciers during the Early Holocene (Palacios et al., 2016). The formerly glaciated 
environments were then subjected to paraglacial processes, which favoured the development

151 of rock glaciers associated to permafrost conditions (Oliva et al., 2016b; 2018b). These

152 permafrost-related landforms finally stabilized at 6-7 ka during the Holocene Climate

153 Optimum, when warmer conditions must have conditioned permafrost thawing (Palacios et

154 al., 2016).

155 Climate variability intensified in the Northern Hemisphere during the Late Holocene

156 (Mayewski et al., 2004). In Sierra Nevada, this was reflected in alternating cold and warm

157 phases (Oliva et al., 2014). During the coldest stages, some glacier spots developed in the

158 highest northern cirques, such as in the Mulhacén cirque, where lake sediments from La

159 Mosca Lake revealed evidence of the existence of a glacier within the cirque at ca. 2.8-2.7 ka

160 cal BP, 1.4-1.2 ka cal BP, and during the LIA between 1440 and 1710 CE (Oliva and Gómez-

161 Ortiz, 2012). For the last cold stage, historical documents also showed evidence of the

162 prevailing colder conditions in Sierra Nevada, with descriptions, sketches and pictures of

163 glaciers and permanent snow fields at the foot of the highest peaks of the westernmost

164 mountains of Sierra Nevada between the late $17^{\text {th }}$ and the early $20^{\text {th }}$ century. The last glacier

165 was located in the Veleta cirque and constituted the southernmost glacier in Europe during the

166 LIA, although it finally melted away during the mid-20 $0^{\text {th }}$ century (Gómez-Ortiz et al., 2001,

167 2009, 2018; Oliva and Gómez-Ortiz, 2012; Oliva et al., 2018a). However, no CRE dating is

168 yet available from the different LIA glacial stages in Sierra Nevada.

\section{3. Methods}

\subsection{Sampling strategy}

171 With the aim of dating glacial landforms formed potentially before the LPG, this research

172 focuses on the Naute valley, a steep mountain ravine located on the southern slope of the

173 Mulhacén peak (Fig. 1, 2, 3 and 4). The valley results from the confluence of two glacial 
174 headwaters -Río Seco and Mulhacén valleys- converging at $2300 \mathrm{~m}$ of altitude. In previous

175 studies these two high mountain valleys were selected to reconstruct glacial stages of the LPG

176 using CRE methods (Gómez-Ortiz et al., 2012; Palacios et al., 2016), but landforms

177 distributed in the lower Naute valley affected by intense erosion processes were not

178 examined. In Río Seco and Mulhacén valleys landforms from the LPG have been already

179 dated using the in situ cosmogenic nuclide ${ }^{36} \mathrm{Cl}$, such as the front of a fossil rock glacier $(9.0$

$180 \pm 0.8 \mathrm{ka})$ resting on polished rock surfaces $(11.9 \pm 1.1 \mathrm{ka})$ in the Río Seco cirque, as well as of

181 a fossil rock glacier $(6.3 \pm 0.5 \mathrm{ka}$ and $13.1 \pm 1.3 \mathrm{ka})$ resting on a polished rock surface $(11.2 \pm$

$182 \quad 1.1 \mathrm{ka}$ and $12.7 \pm 1.2 \mathrm{ka}$ ) at the head of the Mulhacén valley (Palacios et al., 2016). Just

183 before their confluence, both valleys include a sequence of moraine ridges, where 5 blocks

184 were dated using ${ }^{36} \mathrm{Cl}(29.9 \pm 2.6 \mathrm{ka}, 16.9 \pm 1.8 \mathrm{ka}, 14.9 \pm 1.5 \mathrm{ka}, 13.7 \pm 1.3 \mathrm{ka}, 11.7 \pm 1.6 \mathrm{ka}$;

185 Palacios et al., 2016). These authors interpreted these ridges as a polygenic moraine formed

186 by successive advances generated from just before the LGM to the Oldest Dryas. In the Naute

187 valley, immediately below the confluence of these two tributaries, a lateral moraine is

188 preserved in the left sector of the valley at elevations between 2150 and $2300 \mathrm{~m}$. This moraine

189 is placed below one of the ridges where a boulder was dated at $29.9 \pm 2.6 \mathrm{ka}$ (Palacios et al.,

190 2016), and therefore must be older in age, possibly from a previous glaciation. For this

191 reason, this lower moraine was considered as one of the objectives of the work, in order to

192 apply the CRE dating method.

193 To date glacial oscillations during the LIA by CRE dating methods, we focused our research

194 on the Veleta cirque, located under the northern wall of Veleta peak (Fig. 1, 5, 6). Historical

195 documents provided abundant evidence of a glacier existing at the floor of this cirque during

196 the LIA until the first half of the $20^{\text {th }}$ century (Gómez-Ortiz et al., 2001, 2009, 2018). The

197 cirque is closed by a large frontal moraine whose age is unknown, although due to its large 
198 size it has been considered to have formed during the Last Termination or during Holocene

199 advances (Oliva et al., 2014, 2018a).

\subsection{Sampling and analytical procedures}

201 Seven samples were collected from moraine boulders using a hammer and a chisel: four 202 located in Naute valley (NAUT-1, -2, -3, -4) between 2164 and $2263 \mathrm{~m}$, and three in the 203 Veleta cirque (SN-11-1, -2, -3) between 3061 and $3095 \mathrm{~m}$ (Table 1). All samples were taken

204 from the flat-topped surfaces of boulders $>1 \mathrm{~m}$ high, located on the crests of the moraines.

205 Field data and sample characteristics of the seven samples are listed in Table 2.

206 Physical and chemical sample preparation and beryllium measurements were carried out at 207 the Centre Européen de Recherche et d'Enseignement des Géosciences de l'Environnement 208 (CEREGE, France). Lichen, moss and other organic fragments were removed from the 209 samples with a brush. Samples were crushed with a roller grinder and sieved to retrieve the 210 grain size fraction $0.25-1 \mathrm{~mm}$. All samples are quartz-bearing micaschists, and therefore we 211 selected in situ-produced cosmogenic ${ }^{10} \mathrm{Be}$ dating to determine the ages of the moraines. To

212 isolate the quartz from the bulk rock, the samples went repeatedly through a magnetic

213 separator (Frantz LB-1) until all magnetic minerals were discarded. Subsequently, the non-

214 magnetic fraction experienced successive chemical attacks with a mixture of concentrated

215 hydrochloric $(\mathrm{HCl})$ and hexafluorosilic $\left(\mathrm{H}_{2} \mathrm{SiF}_{6}\right)$ acids to dissolve the remaining non-quartz

216 minerals. The residual impurities were dissolved when the sample grains were

217 decontaminated from meteoric ${ }^{10} \mathrm{Be}$ by three successive partial dissolutions with concentrated 218 hydrofluoric acid (HF).

219 The subsequent beryllium extraction protocol is adapted from Brown et al. (1991) and 220 Merchel and Herpers (1999) chemical procedures. The samples yielded between 18 and $32 \mathrm{~g}$ 221 of purified quartz (Table 3). About $100 \mu 1$ of a ${ }^{9} \mathrm{Be}$ carrier solution with a ${ }^{9} \mathrm{Be}$ concentration of 
$3025 \mu \mathrm{g} / \mathrm{g}$ prepared in-house from a phenakite crystal was added to the quartz before it was

223 dissolved in HF. A chemistry blank was prepared along with the seven samples. Following evaporation of the resulting solution, the samples were recovered in a hydrochloric acid solution and beryllium was precipitated to $\mathrm{Be}(\mathrm{OH})_{2}$ with ammonia before and after elution through an anionic exchange column (Dowex 1X8) to remove iron. Following the methods 227 described by Merchel and Herpers (1999), a cationic exchange column (Dowex 50WX8) was 228 used to remove boron and to separate the Be from other elements. Beryllium was precipitated 229 with ammonia to $\mathrm{Be}(\mathrm{OH})_{2}$ and the resulting precipitate was oxidized to $\mathrm{BeO}$ at $700{ }^{\circ} \mathrm{C}$. Then, 230 this final $\mathrm{BeO}$ was mixed with niobium powder and loaded on cathodes for analysis of the $231{ }^{10} \mathrm{Be} /{ }^{9} \mathrm{Be}$ ratios at the French national Accelerator Mass Spectrometry (AMS) facility ASTER 232 (CEREGE) (Arnold et al., 2010). The measurements were calibrated against in-house 233 standard STD-11 using an assigned ${ }^{10} \mathrm{Be} /{ }^{9} \mathrm{Be}$ ratio of $1.191( \pm 0.013) \times 10^{-11}$ (Braucher et al., 234 2015). Sample ${ }^{10} \mathrm{Be} /{ }^{9} \mathrm{Be}$ ratios were corrected for the chemical blank background by 235 subtracting the measured chemistry blank ${ }^{10} \mathrm{Be} /{ }^{9} \mathrm{Be}$ ratio (Table 3). Analytical 1 sigma 236 uncertainties include uncertainties in AMS counting statistics, the uncertainty in the standard

$237{ }^{10} \mathrm{Be} /{ }^{9} \mathrm{Be}$ ratio, an external AMS error of $0.5 \%$ (Arnold et al., 2010), and the uncertainty in the 238 chemical blank measurement. A ${ }^{10}$ Be half-life of $1.387( \pm 0.01) \times 10^{6}$ years was used 239 (Chmeleff et al., 2010; Korschinek et al., 2010).

\subsection{Age calculation ( ${ }^{10}$ Be age computation)}

241 We calculated the ${ }^{10} \mathrm{Be}$ CRE ages with the online CREP exposure age calculator (Martin et 242 al., 2017; http://crep.crpg.cnrs-nancy.fr), using the LSD scaling model (Lifton et al., 2014) 243 that is similar to other previous empirical models (Borchers et al., 2016). Age calculations 244 have also considered the ERA40 atmospheric model (Uppala et al., 2005) and LSD 245 Framework geomagnetic database (Lifton et al., 2014). As there is no regional production rate 246 available, we used the worldwide mean ${ }^{10} \mathrm{Be}$ spallation production rate of $3.99 \pm 0.22$ atoms $\mathrm{g}^{-}$ 
$247{ }^{1} \mathrm{yr}^{-1}$, as calibrated in the ICE-D production rate database linked to CREp. For all samples, a 248 rock density of $2.7 \mathrm{~g} \mathrm{~cm}^{-3}$ was considered and the topographic shielding factor of each sample 249 was calculated (Table 2).

250 In the moraine of the Veleta cirque, from where samples SN-11-1, SN-11-2 and SN-11-3 251 were extracted, snow cover remains for a large part of the year (Gómez-Ortiz et al., 2009), 252 and there is information on the properties and persistence of the snow cover for the last 253 decades (Herrero and Polo, 2016), which allows considering snow shielding effect for these 254 samples. The correction for snow cover has been calculated applying the equation by Gosse 255 and Phillips (2001), including local parameters (Herrero and Polo, 2016), and considering a 256 snow thickness on moraine boulders ranging from 30 to $130 \mathrm{~cm}$ during 8 months per year. We 257 used an average value of snow density of $0.3 \mathrm{~g} \mathrm{~cm}^{-3}$, considering that the attenuation length 258 for fast neutrons in snow is $109 \mathrm{~g} \mathrm{~cm}^{-2}$ (Zweck et al., 2013; Delunel et al., 2014). Taking into 259 account these characteristics, we applied a snow shielding factor of 0.865 to the affected 260 samples. We have not applied a snow shielding factor to the old samples of Naute moraine, 261 since the coverage of snow in this area is much shorter and data are not available for a period 262 encompassing several tens of thousands of years.

263 Table 3 also includes the ages determined with version 3 of the online exposure age calculator 264 formerly known as the CRONUS-Earth online exposure age calculator (Balco et al., 2008; 265 Balco, 2018). These ages have been calculated using the default calibration data set based on 266 the ICE-D calibration database and the time-dependent "LSDn" scaling method (Lifton et al., 267 2014). The average difference between the ages calculated with the CREP exposure age 268 calculator and those calculated with the CRONUS-Earth (v.3) is $2.4 \%$ for NAUT samples and $2696.9 \%$ for $\mathrm{SN}-11$ samples.

270 The ages of the SN-11 samples calculated with the snow shielding factor turn out to be 271 between 8.8 and 16.9\% higher in the online CREP exposure age calculator (Martin et al., 
2017) and between the 7.9 and $16.9 \%$ higher in the online exposure age calculator formerly

273 known as the CRONUS-Earth online exposure age calculator v. 3 (Balco et al., 2008; Balco,

2018). The CREP exposure calculator ages and the analytical uncertainties are used in the text and in the figures of this manuscript and, only in the case of the Veleta cirque, with the application of the snow shielding factor (Table 3).

\section{Results}

\subsection{Geomorphological analysis of the Naute moraine and CRE dating results}

To select the most suitable boulders for CRE dating, an exhaustive survey was carried out of the Naute moraine system, formed potentially during a glacial advance before the LPG. The results of this survey are expressed in a detailed geomorphological map (Fig. 2). The moraine is located on the left bank of the Naute river (west) and the Peñón Grande (east) between 2150 and $2300 \mathrm{~m}$. It has been intensely reshaped by postglacial environmental dynamics: (i) fluvial processes driven by steep streams have deeply eroded the moraine ridge, and (ii) gullying processes have washed away a large part of its abundant fine sediments. As a result, a large number of boulders -highly weathered and fragmented due to their abundant foliation planes and joints- are found on the surface of the moraine (Fig. 3).

To sample the boulders that best represent the original surface of the moraine, we focused on blocks that: (i) present aligned upper edges indicating the maximum possible height of the original moraine crest, and (ii) are inserted into the moraine, which ensures that they have not been mobilized since the moraine stabilization. Using these criteria, only four boulders were found with these characteristics (NAUT-1, 2, 3 and 4) (Fig. 4). The rest of the boulders showed traces of having been affected by erosion and exhumed. 
Samples from two boulders showed a similar age: NAUT-1 yielded $134.8 \pm 6.2 \mathrm{ka}$ and

296 NAUT-4 129.2 $\pm 5.3 \mathrm{ka}$. The other two boulders showed different and substantially younger ages: NAUT-2 obtained $53.7 \pm 2.9 \mathrm{ka}$ and NAUT -4 43.8 $\pm 2.3 \mathrm{ka}$ (Figs 2, 3 and Table 3).

\subsection{Geomorphological analysis of the Veleta cirque moraine and CRE dating results}

299

The Veleta cirque moraine is composed of a large proportion of fine sediments with a few large blocks on the surface, possibly deposited by different glacial advances. Within the area enclosed by this moraine, there are large rock avalanche deposits fallen from the Veleta northern wall and a small rock-glacier where buried glacial ice is still preserved under the debris cover, though it presents evidence of accelerated degradation. On the other hand, the fine sediments of the moraine, resulting from heavily weathered micaschists, are being washed away by runoff activity. This process is particularly intense in late spring and early summer with snowmelt runoff, and in autumn with torrential rain events. The outer slope of the moraine is being reshaped by frequent debris flows, which also facilitate the outcropping and exhumation of large blocks buried in the moraine. In addition, there are some metric-size boulders fallen from the Veleta north wall and deposited on the surface of the moraine, normally during the winter season when snow completely fills the floor of the cirque. These rocks slide on the snow and ice surface and stabilize on the moraine ridge. On the inner slope of the moraine, accumulations are found of superimposed till blocks of different sizes. In contrast to the main moraine, these till deposits include a smaller proportion of fine particles but conserve a recent glacial imprint as revealed by the presence of flutes. This deposit exceeds the limits of the main moraine on the eastern side of the cirque, where the moraine height is lower (Fig. 5 and 6). Evidence from historical sources confirms that the distribution of this recent till deposit coincides with the surface covered by the glacier during the $19^{\text {th }}$ century (Fig. 7; Bide, 1893; Gómez-Ortiz et al., 2018). 
Before selecting boulders for CRE dating, a very detailed geomorphological survey of the

320 large polygenic moraine system enclosing the Veleta cirque was conducted. A detailed

321 geomorphological map shows the main landforms observed in the cirque (Fig. 5). Schematic

322 transects show the sectors of the moraine affected by current or recent post-glacial processes

323 and derived landforms (Fig. 6). Considering these geomorphological characteristics, we

324 avoided collecting samples from blocks corresponding to very recently deglaciated surfaces

325 because: (i) we already know that this area was occupied by the glacier during the $19^{\text {th }}$ century

326 and (ii) they can result from the frequent rockfalls from the headwall. As a result, only three

327 CRE datable boulders were found anchored in the moraine and protruding sufficiently not to

328 have been covered by other sediments since their deposition (SN11-1, 2 and 3) (Fig. 7). Thus,

329 they cannot have fallen from the headwall, or have been covered by the glacier in a

330 subsequent readvance.

331 Sample SN-11-1, collected on the top of the moraine, very close to $20^{\text {th }}$ century till deposits,

332 obtained an age of $340 \pm 120$ years, corresponding to the year $1675 \pm 120$ CE. Sample SN-11-

3332 , collected on the crest of the lobate ridge of the moraine, yielded an age of $720 \pm 270$ years

$334(1295 \pm 270 \mathrm{CE})$. Finally, sample SN-11-3, collected on the top of the lateral moraine ridge in 335 the western part of the cirque, obtained an age of $400 \pm 110$ years (1615 $\pm 110 \mathrm{CE}$ ) (Figs 5, 6 336 and Table 3).

\section{5. Discussion}

3385.1 The existence of a glaciation prior to the last Pleistocene glaciation in Sierra Nevada

339 The results of ${ }^{10} \mathrm{Be}$ CRE dating yielded ages of ca. $130-135 \mathrm{ka}$ for the two samples collected

340 from boulders in the moraine downslope of the maximum ice advance in Sierra Nevada

341 (Gómez-Ortiz et al., 2012). These ages suggest that the moraine may have been formed

342 during the last maximum advance of the penultimate glaciation. The other two boulders of the 
same moraine yield much younger ages, around 45-50 ka (Table 3), and thus can be

344 considered outliers. On the other hand, none of the studies in Sierra Nevada reported boulder

345 samples affected by nuclide inheritance (Gómez-Ortiz et al., 2012; 2015; Palacios et al.,

346 2016), and therefore this problem can be rejected in the older samples.

347 In Sierra Nevada, no surfaces polished and striated bedrock surfaces where found in this study

348 between the moraine ridges dated ca. 130-135 ka and those dated in previous studies between

349 ca. 30 and ca. $15 \mathrm{ka}$ (Palacios et al., 2016), i.e. rock surfaces which may have been ice-

350 covered prior to the LPG. All the polished bedrock surfaces dated in Sierra Nevada -in many

351 cases with abundant and well-preserved fresh striations- correspond to the deglaciation

352 process during Termination I (Gómez-Ortiz et al., 2012; Palacios et al., 2016). The fact that

353 moraines from a previous glaciation are found in close proximity to those of the last glacial

354 cycle without intermediate polished surfaces led us to apply CRE dating only on boulder

355 surfaces in the old moraines. Recent research in mountain areas, such as in the Alps (e.g.

356 Chenet et al., 2016), the Andes (e.g. Martini et al., 2017), Central Asia (e.g. Batbaatar et al.,

357 2018) and the Iberian Peninsula (Rodríguez-Rodríguez et al., 2016, 2017), suggest using a

358 minimum of 5 boulders from the same moraine to ensure obtaining the formation age of the

359 landform. Thus, where most of the results show dispersed data, the ages are rejected, whereas

360 an average value is obtained with the rest, interpreted as indicative of the development age of

361 the moraine. In this study we attempted to apply this five-boulder criterion, but this proved

362 impossible due to the deterioration of the moraine since the penultimate glaciation, as the

363 landform has been intensely eroded and few potentially datable boulders are available. The

364 headwaters of several torrents have eroded the ridge summit, leaving the moraine covered

365 with loose blocks. When trying to reconstruct the original surface of the moraine we found

366 only four embedded boulders (Fig. 4). 
The CRE ages of ca. 130-135 ka obtained in Sierra Nevada coincide with the last cold period

368 of the penultimate glaciation in the Alps as suggested by ${ }^{230} \mathrm{Th}$ dating on speleothems that 369 obtained $131.8 \pm 0.6$ ka (Häuselmann et al., 2015; Moseley et al., 2015). This stage occurred 370 during Heinrich stadial 11 (Oppo et al., 2006), parallel to the end of the last cold phase in the 371 Alboran sea surface temperatures (near Sierra Nevada, in SE Iberia) before the beginning of 372 TII (Martrat et al., 2014; Jiménez-Amat and Zahn, 2015). By that time, the onset of warmer temperatures favored the end of the last cold period of the penultimate glaciation in Greenland (Grant et al., 2012) as well as the initial melting of large ice sheets at high latitudes in the Northern Hemisphere (Govin et al., 2015), leading to sea level rise (Rohling et al., 2017). The formation and stabilization of the Naute moraine may therefore be contemporary with 377 what is called the Penultimate Glacial Maximum (PGM), a parallel concept to the LGM for 378 the last glaciation, centered on $140 \mathrm{ka}$ (Rohling et al., 2017). The deposition age of the Naute moraine is similar to the stabilization age of the maximum glacial advance moraine in the 380 Sierra de Queixa dated $155 \pm 30 \mathrm{ka}{ }^{21} \mathrm{Ne}$ (Vidal-Romaní et al., 2015). The erratic boulder 381 dated $113.9 \pm 7.1 \mathrm{ka}{ }^{10} \mathrm{Be}$ in the Porma Valley, Cantabrian Mountains, could also be related to 382 the deglaciation process following the PGM (Rodríguez-Rodríguez et al., 2016). The same is 383 true for the erratic boulder in the Ariège valley (northern Pyrenees), with a minimum ${ }^{10} \mathrm{Be}$ age of $122.2 \pm 4.9 \mathrm{ka}$ (Delmas et al., 2011), slightly after the formation of the Naute moraine from the penultimate glaciation. In addition, fluvioglacial terraces deposited simultaneously on the outermost moraine ridges in the Gállego and Aragón valleys, Central Pyrenees, were dated

$387151 \pm 11 \mathrm{ka}$ and $171 \pm 22$ ka OSL ages by other authors (Lewis et al., 2009; García-Ruiz et al., 388 2013), and therefore may represent the same glacial stage that led to the formation of the 389 Naute moraine. However, despite some evidence suggesting glacial activity between ca. 170 390 and $130 \mathrm{ka}$ in the Iberian Peninsula, the small number of reliably dated terrestial records 391 makes it difficult to infer spatiotemporal glaciation patterns occurring before the LPG. This is 
a common issue in other Mediterranean mountains where glacial advances concurrent with

393 the development of the Naute moraine have only been dated through the application of $U$ series to secondary carbonates in cemented moraines in mountains in Greece (Hughes et al., 2006a, b, 2007), Dinaric Alps (Hughes et al., 2007) and the Gran Sasso Massif, Central Italy

396 (Kotarba et al., 2001).

397 A case study similar to the Naute moraine was undertaken in the Jura mountains, where

398 several erratic boulders were found scattered beyond the Alpine glaciers LGM extent. In this case the oldest ages were very similar to those of the Naute moraine $(129.7 \pm 4.7 \mathrm{ka}, 143.2 \pm$ $8.2 \mathrm{ka}$ and $144.0 \pm 5.3 \mathrm{ka}{ }^{10} \mathrm{Be}$ ages), although just as in Sierra Nevada, other boulders in the same deposit yielded younger ages (Graf et al., 2015). After their experience applying CRE

402 dating to several moraine boulders in the Himalayas, Schaefer et al. (2008) highlighted the 403 role of erosion processes in the exhumation of blocks in old moraines. As a result, these 404 authors claim that the oldest, not the average age of the moraine boulders reflects the best 405 minimum age estimation for the moraine deposition, in agreement with previous authors (Hallet and Putkonen, 1994). Briner et al. (2005) proposed the same criterion after analyzing a 407 large number of moraine boulders, presumably from the penultimate glaciation in Alaska, and 408 found many problems of boulder exhumations. These authors also defend an "oldest-age method" to provide the closest approximation to the moraine stabilization age. Similarly, and

410 from previous experience, Balco (2011) defined the most appropriate strategies when

411 applying CRE methods to degraded moraines, which have been considered in this study.

412 From our results we conclude that the difficulty of finding suitable boulders to apply CRE

413 methods in moraines from old glaciations should not discourage their use. Dating an adequate 414 number of samples is very difficult for moraines prior to the LPG, where erosive activity over 415 time may have exhumed most of the boulders. In the case of Sierra Nevada, the profoundly 416 tectonized micaschists have been intensely affected by erosion, which makes it more difficult 
to find suitable boulders for dating (Gómez-Ortiz et al., 2015). Nevertheless, Sierra Nevada is

418 an arid mountain, where ice margin deposits preserved on gentle slopes make it possible to

419 obtain a well-dated glacial sequence using the CRE method (Pallàs et al., 2010) (Fig. 9).

\subsection{Chronology of LIA moraine formation in Sierra Nevada}

421 It was also difficult to find suitable blocks for CRE dating in young moraines in Sierra

422 Nevada, as they are found in very dynamic geomorphological environments on steep slopes of $423200 \mathrm{~m}$ high (up to $300 \mathrm{~m}$ from the peaks to the cirque floors) with thick and long-lasting snow 424 cover. On the one hand, these factors accelerate erosion processes in the moraine, often 425 reducing its size, vertical development and the slope gradient; on the other hand, they favor 426 new sediment deposits on the moraine surface. These difficulties are also observed in most 427 Mediterranean mountains, where LIA glaciers did not exceed the limits of the cirques and 428 developed at the foot of vertical walls (Hughes, 2014, 2018). Previous studies adverted to the 429 polygenic character of the Veleta cirque moraine, related to the effects of an Early Holocene 430 glacial advance that pushed downslope, accumulating rockfall deposits from the end of TI 431 (Gómez-Ortiz et al., 2012; Palacios et al., 2016). According to these authors, this moraine 432 system functioned as a barrier to subsequent advances, which accumulated sediments on the 433 inner slope, generating a single, large, polygenic moraine.

434 Using the criteria defined in Methods above, we obtained three coherent results to infer the 435 age of the moraine, although dates were obtained for only three boulders. The high 436 uncertainty levels in our results prevent us from relating the age of each sample to LIA 437 periods (Oliva et al., 2018a). These ages could be related to advances from $1300 \mathrm{CE}$ to $4381610 / 1680 \mathrm{CE}$, contemporary with the LIA maximum glacial advance in the Alps 439 (Holzhauser et al., 2005) and the lowest temperatures in the Iberian Peninsula during the 440 Maunder Minimum (Oliva et al., 2018a). 
The inner slope of the moraine therefore developed during the LIA, although the large

442 moraine system may also include boulders from other Neoglacial glacial stages, such as those

443 detected in the Mulhacén cirque, where lake sediments show evidence of a glacier within the

444 cirque ca. 2.8-2.7 ka, 1.4-1.2 ka cal BP and LIA (Oliva and Gómez-Ortiz, 2012).

445 New results obtained in Mount Olympus (Greece) found similar results using ${ }^{36} \mathrm{Cl}$ dating

446 method, with one sample of $0.64 \pm 0.08 \mathrm{ka}$ (Styllas et al., 2018). However, most studies

447 focusing on the use of CRE dating methods for dating LIA glacial advances have been carried 448 out in the Alps. In the Western Alps, LIA moraines are very close to Neoglacial (Late

449 Holocene) moraines and may even overlap them (Schimmelpfennig et al., 2012; 2014); as in

450 the Veleta cirque, LIA glacial advances have left a single polygenic ridge with dated boulders

451 showing a wide range of dates: $1430 \pm 32,1534 \pm 28$, and $1829 \pm 11 \mathrm{CE}{ }^{10} \mathrm{Be}$ (ages not

452 considering snow shielding) (Schimmelpfennig et al., 2012). These dates could correspond to

453 the three most important glacial advances in the Alps during the LIA: 1300-1380, 1600-1670

454 and 1800-1860 CE (Holzhauser et al., 2005), similar to those detected in the Pyrenees (Oliva

455 et al., 2018a). Recent studies in the Central Alps showed a similar pattern when dating LIA

456 moraine boulders -also very close to or overlapping Neoglacial moraines-forming single

457 polygenic crests (Schimmelpfennig et al., 2014). These authors dated 14 boulders in a single

458 LIA moraine ridge using ${ }^{10} \mathrm{Be}$, assuming negligible inheritance for the boulders, and reported

459 dates ranging from 1430 to $1870 \mathrm{CE}$ (Schimmelpfennig et al., 2014). Le Roy et al. (2017)

460 dated Neoglacial moraines near several present-day glacier fronts in the French Alps and

461 obtained ${ }^{10} \mathrm{Be}$ ages that are all consistent with the Late Holocene period ( 4-1 ka), but do not

462 follow the logical chronostratigraphic moraine sequence. These authors highlighted the

463 problems related to surface exhumation and erosion of many moraine ridges.

464 Some attempts to date the moraines of the LIA have been also made in other high mountain

465 ranges such as the Cordillera Vilcabamba, Central Andes where Licciardi et al. (2009) applied 
${ }^{10} \mathrm{Be} C \mathrm{CRE}$ dating for the first time. Samples collected from a single massive ridge showed average dates ranging from $1740 \pm 30$ to $1810 \pm 20 \mathrm{CE}$, though samples of old dates were rejected as being outliers. They suggest that the moraines found in several valleys of this massif may be the result of the successive accumulation of multiple Late Holocene glacial expansions.

Schaefer et al. (2009) also applied ${ }^{10}$ Be dating in the Mueller valley in the Southern Alps, New Zealand, to date many LIA moraine boulders. The geomorphological setting is similar to that described in the European Alps, with a single LIA moraine system overlapping with various Late Holocene moraine ridges. Boulders taken from different sites in the LIA moraine reported dates of $1350 \pm 60,1600 \pm 50,1780 \pm 40$ and $1820 \pm 20 \mathrm{CE}{ }^{10} \mathrm{Be}$, which coincide with cold periods inferred from tree-ring data. Li et al. (2016) applied ${ }^{10} \mathrm{Be}$ dating in LIA moraines in Tian Shan mountains, Central Asia; interestingly, they found that boulders in moraines from glaciers smaller than $1.0 \mathrm{~km}^{2}$ show very old ages because of nuclide inheritance. The same problems were found in the small Veleta cirque, where the wall is very close to the moraine, but we discarded this possibility following the results obtained in this present study and those from other previous work in Sierra Nevada, because of the intense, continuous rock fall activity on its wall. For larger glaciers, Li et al. (2016) found evidence of a major advance ca. $1600 \pm 100 \mathrm{CE}{ }^{10} \mathrm{Be}$, and also a remarkable early LIA glacial expansion at ca. $1480 \pm 55 \mathrm{CE}{ }^{10} \mathrm{Be}$. Dong et al. (2017) dated two different LIA ridges in Tibetan mountains with ${ }^{10} \mathrm{Be}$, collecting four samples from each ridge. Their results provide a range of $1480 \pm 139$ to $1975 \pm 31 \mathrm{CE}{ }^{10} \mathrm{Be}$ dates for the entire moraine system, very similar to the Veleta cirque results. Young et al. (2015) dated several stable moraine ridges close to the current alpine glacier snouts in Baffin Island and western Greenland and found a logical geomorphological order from $1040 \pm 40 \mathrm{CE}$ to $1700 \pm 40 \mathrm{CE}{ }^{10} \mathrm{Be}$ ages with a retreat from 1750 $\mathrm{CE}$, and proposed a recent glacial maximum during the Medieval Climate Anomaly, when 
491 glaciers in Europe receded. Jomelli et al. (2016) applied in situ cosmogenic ${ }^{36} \mathrm{Cl}$ to date three 492 moraines in Lyngmarksbræen glacier (West Greenland), which were deposited during the last 493 millennium in a relatively flat area not constrained by topography, the opposite that happens 494 in Alpine environments. These authors obtained advances with average ages of $1200 \pm 130$ $495 \mathrm{CE}, 1450 \pm 90 \mathrm{CE}$ and $1720 \pm 60 \mathrm{CE}$ for the most external and internal ridges. The most 496 recent advances coincide with glacial expansion in European high mountains, but the older 497 moraine may have developed during the Medieval Climate Anomaly (Jomelli et al., 2016). In 498 the sub-Antarctic Kerguelen islands, Jomelli et al. (2017) recently dated a moraine with ${ }^{36} \mathrm{Cl}$ 499 that is probably related to the LIA.

500 From a review of the available literature on LIA moraine dating in different mountain ranges, 501 we concluded that, in general, a first glacial advance was recorded during the $14^{\text {th }}$ century, 502 with the major ice expansion during the $17^{\text {th }}$ century and a last minor readvance at the 503 beginning of the $19^{\text {th }}$ century.

504 Due to the short exposure duration of our samples, their ${ }^{10} \mathrm{Be}$ ages have $25-30 \%$ analytical 505 uncertainties. These uncertainties are higher than the age difference of 10-16\% obtained when 506 a snow shielding correction factor is applied, as was proposed in early studies (Benson et al., 507 2004; Schildgen et al., 2005). In any case, this study defends the importance of considering 508 the snow cover of the moraines studied, both when applying CRE methods, and to discover 509 the degree of degradation to which they have been subjected. The location of the glacial fronts 510 during the LIA suggests MAAT ca. $1{ }^{\circ} \mathrm{C}$ below current values in mid-latitude mountain 511 regions (Oliva et al., 2018a), determining longer snow cover duration in the highlands of the 512 glaciated massifs and strengthening shielding from cosmogenic radiation (Fig. 7). Long513 lasting snow cover also intensifies nivation-related erosion processes and can intensely affect 514 glacial deposits (Christiansen, 1998; Palacios et al., 2003). 
515 On the other hand, as we observed in the Veleta cirque, and as described in several papers

516 cited above, the intensity of the paraglacial processes (Ballantyne, 2002; Oliva and Ruiz-

517 Fernández, 2015) in the current deglaciation phase from the LIA advance is very high, with a

518 complex superposition of processes that destroy the glacial landforms and accumulate new

519 deposits on them. Therefore, as we saw, it was difficult to find suitable boulders for CRE

520 dating in the Veleta cirque, despite its young age. In this context, the long-term study and

521 monitoring of the dynamics of the LIA moraines in full paraglacial phase, should serve to

522 evaluate the time needed for moraine stabilization, once it has been abandoned by glacial

523 retreat (Zreda and Phillips, 1994,1995; Putkonen and O’Neal, 2006; Putkonen et al., 2008;

524 Heyman et al., 2011) (Fig. 9).

525 In areas where LIA moraines are constrained by steep slopes, as is very common in Alpine

526 systems, at least two, or possibly three, major LIA advances overlap, in some cases with other

527 Neoglacial moraines, to form a single polygenic ridge, as occurred in the Veleta cirque. This

528 was highlighted in the mid-1980s with the concepts of "obliterative overlap" (Gibbons et al.,

529 1984) and "distal-flank accretion" (Osborn, 1986) applied to Neoglacial advances.

\section{6. Conclusions}

531 The results of this research supply evidence of the very few CRE dates available on very old 532 glacial landforms formed before the last Pleistocene glaciation, and also the few very young 533 dates available, such as those derived from LIA glaciation, compared with the large number

534 of dates obtained for Termination I. For both periods, the selection of boulders suitable for 535 sampling was the critical issue in Sierra Nevada, due to intense postglacial environmental 536 dynamics such as occurred during the last major deglaciation, which impedes the collection of 537 a statistically significant number of samples. In the case of the LIA, moraines are still 538 undergoing intense paraglacial readjustment to the new geomorphological setting, with very intense erosion and sediment redistribution of the unconsolidated moraine particles. In 
addition, moraine accretion processes during successive glacial advances are detected from

541 geomorphological observations. In moraines originating during the penultimate glaciation, the

542 long time lapse since their formation has facilitated intense erosion and reshaping of these

543 landforms, with very few stable blocks remaining on the surface since their original

544 stabilization. Periods of certain geomorphic stability may have occurred between the very old 545 and the younger glaciations (Fig. 9).

546 The results of this research have enabled us to verify the existence of moraines deposited in 547 glaciations prior to LPG in Sierra Nevada, as many of the first geomorphologists who studied 548 the glacial landforms of this mountains suggested, and confirm similar CRE and OSL ages 549 established in other mountains in the northern Iberian Peninsula.

550 In addition, CRE dates are obtained for the first time in the Iberian Peninsula in LIA 551 moraines, with results suggesting that maximum advances during this period occurred 552 between the $14^{\text {th }}$ and $17^{\text {th }}$ centuries, as is the case in many other mountains where the same 553 method has been applied.

\section{Acknowledgments}

556 The research was carried out within the MOUNTAIN WARMING project (CGL2015-65813557 R). Marc Oliva is grateful for the support of the Ramón y Cajal research program (RYC558 2015-17597) and the ANTALP research group (Antarctic, Arctic, Alpine Environments, 559 2017-SGR-1102). The ${ }^{10}$ Be measurements were performed at the ASTER AMS National 560 facility (CEREGE, Aix en Provence) which is supported by the INSU/CNRS, the ANR 561 through the "Projets thématiques d'excellence" program for the "Equipements d'excellence" 562 ASTER-CEREGE action and IRD. The authors express their deep gratitude to Dr. Magali 
563 Delmas and two anonymous reviewers whose detailed and interesting suggestions have

564 helped to improve our manuscript.

565

566

567

568

569

570

571

572

573

574

575

576

577

578

579

580

581

582

583

584

585

586

\section{References}

Arnold, M., Merchel, S., Bourles, D., Braucher, R., Benedetti, L., Finkel, R.C., Aumaître, G., Gottdang, A., Klein, M., 2010. The French accelerator mass spectrometry facility ASTER: improved performance and developments. Nucl. Instrum. Methods Phys. Res. B 268, 1954-1959.

Balco, G., Stone, J. O., Lifton, N. A., Dunai, T.J., 2008. A complete and easily accessible means of calculating surface exposure ages or erosion rates from ${ }^{10} \mathrm{Be}$ and ${ }^{26} \mathrm{Al}$ measurements. Quaternary geochronology 3(3), 174-195.

Balco, G., 2011. Contributions and unrealized potential contributions of cosmogenic-nuclide exposure dating to glacier chronology, 1990-2010. Quat. Sci. Rev. 30(1-2), 3-27.

Balco, G. 2018. CRONUS-Earth online exposure age calculator v. 3. Available at: http://hess.ess.washington.edu/math/v3/v3_age_in.html (accessed_June, 2018)

Ballantyne, C.K., 2002. Paraglacial geomorphology. Quat. Sci. Rev. 21(18-19), 1935-2017.

Barrère, P., 1953. Equilibrie glacier actuel et quaternaire dans 1'Ouest des Pyrénèes Centrales. Revue geographique des Pyrénèes et du Sud-Ouest 2, 116-134.

Batbaatar, J., Gillespie, A. R., Fink, D., Matmon, A., Fujioka, T., 2018. Asynchronous glaciations in arid continental climate. Quat. Sci. Rev. 182, 1-19.

Benson, L., Madole, R., Phillips, W., Landis, G., Thomas, T., Kubik, P., 2004. The probable importance of snow and sediment shielding on cosmogenic ages of north-central Colorado Pinedale and pre-Pinedale moraines. Quat. Sci. Rev. 23, 193-206.

Bide, J.B., 1893. Deuxième excursion dans la Sierra Nevada. Annuaire du Club Alpin Français 20, 276-305. 
Borchers, B., Marrero, S., Balco, G., Caffee, M., Goehring, B., Lifton, N., Nishiizumi, K., Phillips, F., Schaefer, J., Stone, J., 2016. Geological calibration of spallation production rates in the CRONUS-Earth project. Quat. Geochronol. 31, 188-198.

Braucher, R., Guillou, V., Bourles, D., Arnold, M., Aumaître, G., Keddadouche, K., Nottoli, E., 2015. Preparation of ASTER in-house ${ }^{10} \mathrm{Be} /{ }^{9} \mathrm{Be}$ standard solutions. Nuclear Instruments and Methods in Physics Research Section B: Beam Interactions with Materials and Atoms 361, 335-340.

Briner, J.P., Kaufman, D.S., Manley, W.F., Finkel, R.C., Caffee, M.W., 2005. Cosmogenic exposure dating of late Pleistocene moraine stabilization in Alaska. Geological Society of America Bulletin 117(7-8), 1108-1120.

Brown, E.T., Edmond, J.M., Raisbeck, G.M., Yiou, F., Kurz, M.D., Brook, E.J., 1991. Examination of surface exposure ages of Antarctic moraines using in-situ produced ${ }^{10} \mathrm{Be}$ and ${ }^{26} \mathrm{Al}$. Geochimica Cosmochimica Acta 55, 2269-2283.

Chenet, M., Brunstein, D., Jomelli, V., Roussel, E., Rinterknecht, V., Mokadem, F., ASTER Team, 2016. ${ }^{10} \mathrm{Be}$ cosmic-ray exposure dating of moraines and rock avalanches in the Upper Romanche valley (French Alps): Evidence of two glacial advances during the Late Glacial/Holocene transition. Quat. Sci. Rev. 148, 209-221.

Chmeleff, J., von Blanckenburg, F., Kossert, K., Jakob, J., 2010. Determination of the ${ }^{10}$ Be half-life by multicollector ICP-MS and liquid scintillation counting. Nucl. Instrum. Methods Phys. Res. B 268 (2), 192-199.

Clark, P.U., Dyke, A.S., Shakun, J.D., Carlson, A.E., Clark, J., Wohlfarth, B., Mitrovica, J.X., Hostetler, S.W., McCabe, A.M., 2009. The Last Glacial Maximum. Science 325, 710714. 
610 Christiansen, H.H., 1998. Nivation forms and processes in unconsolidated sediments, NE Greenland. Earth Surface Processes and Landforms: The Journal of the British Geomorphological Group 23(8), 751-760.

613 Delmas, M., Calvet, M., Gunnell, Y., Braucher, R., Bourlès, D., 2011. Palaeogeography and 10Be exposure-age chronology of Middle and Late Pleistocene glacier systems in the northern Pyrenees: implications for reconstructing regional palaeoclimates. Palaeogeogr. Palaeoclimatol. Palaeoecol. 305, 109-122.

Delmas, M., 2015. The last maximum ice extent and subsequent deglaciation of the Pyrenees: an overview of recent research. Cuadernos de Investigación Geográfica 41, 359-387.

Delunel, R., Bourlès, D.L., van der Beek, P.A., Schlunegger, F., Leya, I., Masarik, J., Paquet, E., 2014. Snow shielding factors for cosmogenic nuclide dating inferred from longterm neutron detector monitoring. Quat. Geochronol. 24, 16-26.

Domínguez-Villar, D., Carrasco, R.M., Pedraza, J., Cheng, H., Edwards, R. L., Willenbring, J.K., 2013. Early maximum extent of paleoglaciers from Mediterranean mountains during the LPG. Scientific Reports 3, 2034.

Dong, G., Zhou, W., Yi, C., Zhang, L., Li, M., Fu, Y., Zhang, Q., 2017. Cosmogenic ${ }^{10}$ Be surface exposure dating of 'Little Ice Age' glacial events in the Mount Jaggang area, central Tibet. The Holocene 27(10), 1516-1525.

Fernández-Fernández J.M., Palacios D., García-Ruiz, J.M., Andrés,N., Schimmelpfennig, I., Gómez-Villar, A., Santos-González, J., Álvarez-Martínez, J., Arnáez, J., Úbeda, J., Léanni, L., ASTER Team, 2017. Chronological and geomorphological investigation of fossil debris-covered glaciers in relation to deglaciation processes: A case study in the Sierra de La Demanda, northern Spain. Quat. Sci. Rev. 170, 232-249. 
García-Ruiz, J.M., Martí-Bono, C., Peña-Monné, J.L., Sancho, C., Rhodes, E.J., Valero-Garcés, B., Moreno, A., 2013. Glacial and fluvial deposits in the Aragón valley, central-western Pyrenees: chronology of the Pyrenean late pleistocene glaciers. Geografiska Annaler: Series A, Physical Geography 95(1), 15-32.

García-Ruiz, J.M., Moreno, A., González-Sampériz, P., Valero-Garcés, B., Martí-Bono, C., 2010. La cronología del último ciclo glaciar en las montañas del sur de Europa. Una revisión. Cuaternario y Geomorfología 24, 35-46.

García-Ruiz, J. M., Palacios, D., González-Sampériz, P., Andrés, N., Moreno, A., ValeroGarcés, B., Gómez-Villar, A..2 2016. Mountain glacier evolution in the Iberian Peninsula during the Younger Dryas. Quat. Sci. Rev. 138, 16-30.

García-Ruiz, J.M., Palacios, D., de Andrés, N., Valero-Garcés, B.L., López-Moreno, J.I., Sanjuán, Y., 2014. Holocene and 'Little Ice Age' glacial activity in the Marboré Cirque, Monte Perdido Massif, Central Spanish Pyrenees. The Holocene 24 (11), 1439-1452. doi.org/10.1177/0959683614544053

Gibbons, A.B., Megeath, J.D., Pierce, K.L., 1984. Probability of moraine survival in a succession of glacial advances. Geology 12(6), 327-330.

Gómez-Ortiz, A., Oliva, M., Salvador-Franch, F., Salvà-Catarineu, M., Plana-Castellví, J.A., 2018. The geographical interest of historical documents to interpret the scientific evolution of the glacier existing in the Veleta cirque (Sierra Nevada, Spain) during the Little Ice Age. Cuadernos de Investigación Geográfica 44 (1), 267-292.

Gómez-Ortiz, A., Palacios, D., Oliva, M., Salvador-Franch, F., Salvà-Catarineu, M., 2015. The deglaciation of Sierra Nevada (Spain): synthesis of current knowledge and new contributions. Cuadernos de Investigación Geográfica 41 (2), 409-426. 
658 Gómez-Ortiz, A., Palacios, D., Palade, B., Vázquez-Selem, L., Salvador-Franch, F., 2012.

The deglaciation of the Sierra Nevada (southern Spain). Geomorphology 159-160, $93-$ 105.

Gómez-Ortiz, A., Palacios, D., Palade, B., Vázquez-Selem, L., Salvador-Franch, F., Tanarro, L., Oliva, M., 2013. La evolución glaciar de Sierra Nevada y la formación de glaciares rocosos. Boletín de la Asociación de Geógrafos Españoles 61, 139-162.

Gómez-Ortiz, A., Palacios, D., Ramos, M., Tanarro, L.M., Schulte, L., Salvador, F., 2001. Location of permafrost in marginal regions: Corral del Veleta, Sierra Nevada, Spain. Permafrost and Periglacial Processes 12, 93-110.

Gómez-Ortiz, A., Palacios, D., Schulte, L., Salvador-Franch, F., Plana, J.A., 2009. Evidences from historical documents of landscape evolution after Little Ice Age of a Mediterranean high mountain area, Sierra Nevada, Spain (eighteenth to twentieth centuries). Geografiska Annaler, Series A, Physical Geography 91, 279-289.

González-Trueba, J.J., Martín, R., Martínez de Pisón, E., Serrano, E., 2008. 'Little Ice Age' glaciation and current glaciers in the Iberian Peninsula. The Holocene 18, 551-568.

Gosse, J.C., Phillips, F.M., 2001. Terrestrial in situ cosmogenic nuclides: theory and application. Quat. Sci. Rev. 20, 1475-1560. http://dx.doi.org/10.1016/S0277$3791(00) 00171-2$.

Govin, A., Capron, E., Tzedakis, P. C., Verheyden, S., Ghaleb, B., Hillaire-Marcel, C., Blunier, T., 2015. Sequence of events from the onset to the demise of the Last Interglacial: Evaluating strengths and limitations of chronologies used in climatic archives. Quat. Sci. Rev. 129, 1-36.

Graf, A., Akçar, N., Ivy-Ochs, S., Strasky, S., Kubik, P.W., Christl, M., Schlüchter, C., 2015. Multiple advances of Alpine glaciers into the Jura Mountains in the Northwestern Switzerland. Swiss Journal of Geosciences 108(2-3), 225-238. 
Grant, K.M., Rohling, E.J., Bar-Matthews, M., Ayalon, A., Medina-Elizalde, M., Ramsey, C.B., Roberts, A.P., 2012. Rapid coupling between ice volume and polar temperature over the past 150,000 years. Nature 491(7426), 744 .

Hallet, B., Putkonen, J., 1994. Surface Dating of dynamic landforms: Young boulders on aging moraines. Science 265, 937-940.

Häuselmann, A.D., Fleitmann, D., Cheng, H., Tabersky, D., Günther, D., Edwards, R.L., 2015. Timing and nature of the penultimate deglaciation in a high alpine stalagmite from Switzerland. Quat. Sci. Rev. 126, 264-275.

Hempel, L., 1960. Límites altitudinales geomorfológicos en Sierra Nevada. Estudios Geográficos 78, 81-93.

Herrero, J., Polo, M.J., 2016. Evaposublimation from the snow in the Mediterranean mountains of Sierra Nevada (Spain). The Cryosphere 10(6), 2981.

Heyman, J., Stroeven, A.P., Harbor, J.M., Caffee, M.W., 2011. Too young or too old: evaluating cosmogenic exposure dating based on an analysis of compiled boulder exposure ages. Earth Planet. Sci. Lett. 302, 71-80

Holzhauser, H., Magny, M., and Zumbühl, H.J., 2005. Glacier and lake-level variations in west-central Europe over the last 3500 years: The Holocene 15, 789-801. http://dx.doi.org/10.1191/0959683605hl853ra.

Hughes, P.D., 2014. Little Ice Age glaciers in the Mediterranean mountains. Mediterranée $122,63-79$.

Hughes, P.D., 2018. Little Ice Age glaciers and climate in the Mediterranean mountains: a new analysis. Cuadernos de Investigación Geográfica 44 (1), 15-45.

Hughes, P.D., Woodward, J.C., Gibbard, P.L., 2007. Middle Pleistocene cold stage climates in the Mediterranean: new evidence from the glacial record. Earth and Planetary Science Letters 253(1-2), 50-56. 
Hughes, P.D., Woodward, J.C., Van Calsteren, P.C., Thomas, L.E., 2011. The glacial history of the Dinaric Alps, Montenegro. Quat. Sci. Rev. 30(23-24), 3393-3412.

Hughes, P.D., Woodward, J.C., Gibbard, P.L., 2006a. Glacial history of the Mediterranean mountains. Progress in Physical Geography 30, 334- 364.

Hughes, P.D., Woodward, J.C., Gibbard, P.L., 2006b. Late Pleistocene glaciers and climate in the Mediterranean region. Global and Planetary Change 46, 83-98.

Heyman, J., Stroeven, A.P., Harbor, J.M., Caffee, M.W., 2011. Too young or too old: evaluating cosmogenic exposure dating based on an analysis of compiled boulder exposure ages. Earth-Planet. Sci. Lett. 302, 71-80.

Jiménez-Amat, P., Zahn, R., 2015. Offset timing of climate oscillations during the last two glacial-interglacial transitions connected with large-scale freshwater perturbation. Paleoceanography 30(6), 768-788.

Jomelli, V., Mokadem, F., Schimmelpfennig, I., Chapron, E., Rinterknecht, V., Favier, V., Swingedouw, D., 2017. Sub-Antarctic glacier extensions in the Kerguelen region (49 ${ }^{\circ}$ $\mathrm{S}$, Indian Ocean) over the past 24,000 years constrained by ${ }^{36} \mathrm{Cl}$ moraine dating. Quat. Sci. Rev. 162, 128-144.

Jomelli, V., Lane, T., Favier, V., Masson-Delmotte, V., Swingedouw, D., Rinterknecht, V., Leanni, L., 2016. Paradoxical cold conditions during the medieval climate anomaly in the Western Arctic. Scientific Reports 6, 32984.

Korschinek, G., Bergmaier, A., Faestermann, T., Gerstmann, U.C., Knie, K., Rugel, G., Wallner, A., Dillmann, I., Dollinger, G., von Gostomski Lierse, Ch., Kossert, K., Maitia, M., Poutivtsev, M., Remmert, A., 2010. A new value for the half-life of 10Be by heavy-ion elastic recoil detection and liquid scintillation counting. Nucl. Instrum. Methods Phys. Res. B 268 (2), 187-191. 
Kotarba A., Hercman H., Dramis, F., 2001. On the age of Campo Imperatore glaciations, Gran Sasso Massif, Central Italy. Geografia Fisica e Dinamica Quaternaria 24, 65-69.

Le Roy, M., Deline, P., Carcaillet, J., Schimmelpfennig, I., Ermini, M., ASTER Team, 2017.

${ }^{10} \mathrm{Be}$ exposure dating of the timing of Neoglacial glacier advances in the EcrinsPelvoux massif, southern French Alps. Quat. Sci. Rev. 178, 118-138.

Lewis, C.J., McDonald, E.V., Sancho, C., Peña, J.L., Rhodes, E.J., 2009. Climatic implications of correlated Upper Pleistocene glacial and fluvial deposits on the Cinca and Gállego rivers (NE Spain) based on OSL dating and soil stratigraphy. Global and Planetary Change 67, 141-152.

Lhenaff, R., 1977. Recherches géomorphologiques sur les Cordillères Bétiques centrooccidentales (Espagne). PhD thesis, University of Lille.

Li, Y., Li, Y., Harbor, J., Liu, G., Yi, C., Caffee, M.W., 2016. Cosmogenic ${ }^{10}$ Be constraints on Little Ice Age glacial advances in the eastern Tian Shan, China. Quat. Sci. Rev. $138,105-118$.

Licciardi, J.M., Schaefer, J.M., Taggart, J.R., Lund, D.C., 2009. Holocene glacier fluctuations in the Peruvian Andes indicate northern climate linkages. Science 325, 1677-1679. http://dx.doi.org/10.1126/science.1175010.

Lifton, N., Sato, T., Dunai, T.J., 2014. Scaling in situ cosmogenic nuclide production rates using analytical approximations to atmospheric cosmic-ray fluxes. Earth Planet. Sci. Lett. 386, 149-160.

Martin, L., Blard, P.-H., Balco, G., Lave, J., Delunel, R., Lifton, N., Laurent, V., 2017. The CREp program and the ICE-D production rate calibration database: a fully parameterizable and updated online tool to compute cosmic-ray exposure ages. Quat. Geochronol. 38, 25-49. 
Martini, M.A., Kaplan, M.R., Strelin, J.A., Astini, R.A., Schaefer, J.M., Caffee, M.W., Schwartz, R., 2017. Late Pleistocene glacial fluctuations in Cordillera Oriental, subtropical Andes. Quat. Sci. Rev. 171, 245-259.

Martrat, B., Jimenez-Amat, P., Zahn, R., Grimalt, J.O., 2014. Similarities and dissimilarities between the last two deglaciations and interglaciations in the North Atlantic region. Quat. Sci. Rev. 99, 122-134.

Mayewski, P.A., Rohling, E.E., Stager, C., Karlén, W., Maasch, K.A., Meeker, L.D., Meyerson, E.A., Gasse, F., Van Kreveld, S., Holmgren, K., Leethrop, J., Rosqvist, G., Rack, F., Staubwasser, M., Schneider, R.R., Steig, E.J., 2004. Holocene climate variability. Quaternary Research 62 (3), 243-255.

Merchel, S., Herpers, U., 1999. An update on radiochemical separation techniques for the determination of longlived radionuclides via Accelerator Mass Spectrometry. Radiochim. Acta 84, 215-219.

Messerli, B., 1965. Beiträge zur Geomorphologie der Sierra Nevada (Andalusien). Juris Verlag. Zürich.

Moseley, G.E., Spötl, C., Cheng, H., Boch, R., Min, A., Edwards, R.L., 2015. Termination-II interstadial/stadial climate change recorded in two stalagmites from the north European Alps. Quat. Sci. Rev. 127, 229-239.

Nussbaum, F., 1949. Sur les traces des glaciers quaternaires dans la région de l'Aragón. Pirineos 13-14, 497-518.

Obermaier, H., 1914. Estudio de los glaciares de los Picos de Europa. Museo Nacional de Ciencias Naturales, Madrid.

Obermaier, H., 1916. Los glaciares cuaternarios de Sierra Nevada. Trabajos del Museo Nacional de Ciencias Naturales (Geología) 17, 1-68. 
Obermaier, H., Carandell, J., 1917. Los glaciares cuaternarios de la Sierra de Guadarrama. Trabajos del Museo Nacional de Ciencias Naturales, 19, 1-92.

Oliva, M., Gómez-Ortiz, A. 2012. Late Holocene environmental dynamics and climate variability in a Mediterranean high mountain environment (Sierra Nevada, Spain) inferred from lake sediments and historical sources. The Holocene 22 (8), 915-927.

Oliva, M., Gómez-Ortiz, A., Palacios, D., Salvador-Franch, F., Salvà-Catarineu, M., 2014. Environmental evolution in Sierra Nevada (South Spain) since the LPG based on multi-proxy records. Quaternary International 353, 195-209.

Oliva, M., Ruiz-Fernández, J. 2015. Coupling patterns between paraglacial and permafrost degradation responses in Antarctica. Earth Surface Processes and Landforms 40 (9), $1227-1238$.

Oliva, M., Ruiz-Fernández, J., Barriendos, M., Benito, G., Cuadrat, J.M., García-Ruiz, J.M., Giralt, S., Gómez-Ortiz, A., Hernández, A., López-Costas, O., López-Moreno, J.I., López-Sáez, J.A., Martínez-Cortizas, A., Moreno, A., Prohom, M., Saz, M.A., Serrano, E., Tejedor, E., Trigo, R., Valero-Garcés, B., Vicente-Serrano, S., 2018a. The Little Ice Age in Iberian mountains. Earth-Science Reviews 177, 175-208.

Oliva, M., Žebre, M., Guglielmin, M., Çiner, A., Vieira, G., Bodin, X., Andrés, N., Colucci, R.R., García-Hernández, C., Hughes, P., Mora, C., Nofre, J., Palacios, D., PérezAlberti, A., Ribolini, A., Ruiz-Fernández, J., Sarıkaya, M.A., Serrano, E., Urdea, P., Valcárcel, M., Woodward, J., Yıldırım, C., 2018b. Permafrost conditions in the Mediterranean region since the LPG. Earth-Science Reviews 185, 397-436.

Oliva, M., Serrano, E., Gómez-Ortiz, A., González Amuchastegui, M.J., Nieuwendam, A., Palacios, D., Pellitero-Ondicol, R., Pérez-Alberti, A., Ruiz-Fernández, J., Valcárcel, M., Vieira, G., 2016b. Spatial and temporal variability of periglaciation of the Iberian Peninsula. Quat. Sci. Rev., 137, 176-199. 
Oliva, M., Gómez-Ortiz, A., Salvador-Franch, F., Salvà-Catarineu, M., Ramos, M., Palacios, D., Tanarro, L., Pereira, P., Ruiz-Fernández, J., 2016a. Inexistence of permafrost at the top of Veleta peak (Sierra Nevada, Spain). Science of the Total Environment 550, 484494.

Oppo, D.W., J.F. McManus, Cullen, J. L., 2006. Evolution and demise of the last interglacial warmth in the subpolar North Atlantic, Quat. Sci. Rev. 25, 3268-3277.

Osborn, G., 1986. Lateral-moraine stratigraphy and neoglacial history of Bugaboo Glacier, British Columbia. Quaternary Research 26(2), 171-178.

Palacios, D., de Andrés, N., Luengo, E., 2003. Distribution and effectiveness of nivation in Mediterranean mountains: Peñalara (Spain). Geomorphology 54(3-4), 157-178.

Palacios, D., Andrés, N., Gòmez-Ortiz, A., García-Ruiz, J.M., 2017a. Evidence of glacial activity during the Oldest Dryas in the Mountain of Spain. In: Hughes, P. and Woodward, J. (Eds.) Quaternary glaciation in the Mediterranean Mountains. Geological Society of London, Special Publication, 433(1), 87-110. doi.org/10.1144/SP433.10

Palacios, D., García-Ruiz, J.M., Andrés, N., Schimmelpfennig, I., Campos, N. Leanni, L., ASTER Team, 2017b. Deglaciation in the central Pyrenees during the PleistoceneHolocene transition: Timing and geomorphological significance. Quat. Sci. Rev. 162, 111-127. doi.org/10.1016/j.quascirev. 2017.03.007

Palacios, D., Gómez-Ortiz, Andres, N., Salvador, F., Oliva, M., 2016. A Timing and new geomorphologic evidence of the last deglaciation stages in Sierra Nevada (southern Spain) Quat. Sci. Rev. 150, 110-129 doi.org/10.1016/j.quascirev.2016.08.012

Pallàs, R., Rodes, A., Braucher, R., Bourles, D., Delmas, M., Calvet, M., Gunnell, Y. 2010. Small, isolated glacial catchments as priority target for cosmogenic surface dating of Pleistocene climate fluctuations, SE Pyrenees. Geology 38, 891-894. 
Palma, P., Oliva, M., García-Hernández, C., Gómez Ortiz, A., Ruiz-Fernández, J., SalvadorFranch, F., Catarineu, M., 2017. Spatial characterization of glacial and periglacial landforms in the highlands of Sierra Nevada (Spain). Sci. Total Environ. 584-585, 1256-1267. https://doi.org/10.1016/j.scitotenv.2017.01.196

Penck, A., 1883. La période glaciaire dans les Pyrénées. Bulletin de la Société d’Histoire Naturelle de Toulouse 19, 105-200.

Penck, A., 1897. Die Picos de Europa und das kantabrische Gebirge. Geographische Zeitschrift, 278-281.

Putkonen, J., Swanson, T., 2003. Accuracy of cosmogenic ages for moraines. Quaternary Research. 59, 255-261.

Putkonen, J., Connolly, J., Orloff, T., 2008. Landscape evolution degrades the geologic signature of past glaciations. Geomorphology 97, 208-217.

Putkonen, J., O’Neal, M., 2006. Degradation of unconsolidated Quaternary landforms in the western North America. Geomorphology 75, 408-419.

Quelle, O., 1908. Beiträge zur Kenntnis der spanischen Sierra Nevada. Friedrich-Wilheilms Universität, Berlin.

Rodríguez-Rodríguez, L., Jiménez-Sánchez, M., Domínguez-Cuesta, M.J., Rinterknecht, V., Pallàs, R., Bourlès, D., 2016. Chronology of glaciations in the Cantabrian Mountains (NW Iberia) during the Last Glacial Cycle based on in situ-produced ${ }^{10}$ Be. Quat. Sci. Rev. 138, 31-48.

Rodríguez-Rodríguez, L., Jiménez-Sánchez, M., Domínguez-Cuesta, M.J., Rinterknecht, V., Pallàs, R., Aumaître, G., Bourlès, D.L., Keddadouche, K., 2017. Timing of last deglaciation in the Cantabrian Mountains (Iberian Peninsula; North Atlantic Region) based on in situ-produced ${ }^{10}$ Be exposure dating. Quat. Sci. Rev. 171, 166-181. https://doi.org/10.1016/j.quascirev.2017.07.012 
Rohling, E.J., Hibbert, F.D., Williams, F.H., Grant, K.M., Marino, G., Foster, G. L., Webster, J.M., 2017. Differences between the last two glacial maxima and implications for icesheet, $\delta^{18} \mathrm{O}$, and sea-level reconstructions. Quat. Sci. Rev. 176, 1-28.

Sánchez-Gómez, S., 1990. Aplicación del estudio de suelos a la dinámica de la cuenca del río Lanjarón. Relación suelos-geomorfología. PhD thesis, University of Granada.

Sanz de Galdeano, C., López-Garrido, A.C., 1999. Nature and impact of the Neotectonic deformation in the western Sierra Nevada (Spain). Geomorphology 30 (3), 259-272.

Schaefer, J.M., Oberholzer, P., Zhao, Z., Ivy-Ochs, S., Wieler, R., Baur, H., Schlüchter, C. 2008. Cosmogenic beryllium-10 and neon-21 dating of late Pleistocene glaciations in Nyalam, monsoonal Himalayas. Quat. Sci. Rev. 27(3-4), 295-311.

Schaefer, J.M., Denton, G.H., Kaplan, M., Putnam, A., Finkel, R.C., Barrell, D.J.A., Andersen, B.G., Schwartz, R., Mackintosh, A., Chinn, T., Schlüchter, C., 2009. High frequency Holocene glacier fluctuations in New Zealand differ from the northern signature. Science 324, 622-625. http://dx.doi.org/10.1126/science.1169312.

Schildgen, T.F., Phillips, W.M., Purves, R.S., 2005. Simulation of snow shielding corrections for cosmogenic nuclide surface exposure studies. Geomorphology 64, 67-85.

Schimmelpfennig, I., Schaefer, J.M., Akçar, N., Ivy-Ochs, S., Finkel, R.C., Schlüchter, C., 2012. Holocene glacier culminations in the Western Alps and their hemispheric relevance. Geology 40, 891-894. doi:10.1130/G33169.1

Schimmelpfennig, I., Schaefer, J.M., Akçar, N., Koffman, T., Ivy-Ochs, S., Schwartz, R., Finkel, R.C., Zimmerman, S., Schlüchter, C., 2014. A chronology of Holocene and Little Ice Age glacier culminations of the Steingletscher, Central Alps, Switzerland, based on high-sensitivity beryllium-10 moraine dating. Earth and Planetary Science Letters 393, 220-230. 
Styllas, M.N., Schimmelpfennig, I., Benedetti, L., Ghilardi, M., ASTER Team, 2018. Lateglacial and Holocene history of the northeast Mediterranean mountains-New insights from in situ-produced 36Cl-based cosmic ray exposure dating of paleo-glacier deposits on Mount Olympus, Greece. Quat. Sci. Rev. 193, 244-265.

Uppala, S.M., Kållberg, P., Simmons, A., Andrae, U., Bechtold, V., Fiorino, M., Gibson, J., Woollen, J., 2005. The ERA-40 reanalysis. Q.J.R. Meteorological Soc. 131, 29613012.

Vidal-Romaní, J.R., Fernández-Mosquera, D., Marti, K., 2015. The glaciation of Serra de Queixa-Invernadoiro and Serra do Gerês-Xurés, NW Iberia. A critical review and a cosmogenic nuclide $\left({ }^{10} \mathrm{Be}\right.$ and $\left.{ }^{21} \mathrm{Ne}\right)$ chronology. Cadernos do Laboratorio Xeolóxico de Laxe 38, 25-44.

Villa, E., Stoll, H., Farias, P., Adrados, L., Edwards, R.L., Cheng, H., 2013. Age and significance of the Quaternary cemented deposits of the Duje Valley (Picos de Europa, Northern Spain). Quaternary Research 79, 1-5.

Young, N.E., Schweinsberg, A.D., Briner, J.P., Schaefer, J.M., 2015. Glacier maxima in Baffin Bay during the Medieval Warm Period coeval with Norse settlement. Science advances 1(11), e1500806.

Zreda, M.G., Phillips, F.M., 1995. Insights into alpine moraine development from cosmogenic ${ }^{36} \mathrm{Cl}$ buildup dating. Geomorphology $14(2), 149-156$.

Zreda, M.G., Phillips, F.M., 1994. Cosmogenic ${ }^{36} \mathrm{Cl}$ accumulation in unstable landforms. Water Resources Research 30, 3127-3136.

Zweck, C., Zreda, M., Desilets, D., 2013. Snow shielding factors for cosmogenic nuclide dating inferred from Monte Carlo neutron transport simulations. Earth Planet Sci. Lett. 379, 64-71. http://dx.doi.org/10.1016/j.eps1.2013.07.023. 
Figure 1. Location of the case study area, Sierra Nevada, in the south of the Iberian Peninsula. ka ages from this work (NAUT samples) together with those from Palacios et al. (2016).

Figure 3. Results of the Naute moraine samples of this work, together with pictures of some

909 of the sampled boulders and CRE data (including data from Palacios et al. (2016)). (A)

910 Penultimate glaciation moraine (source: Google Earth imagery), (B) Picture of the sampled

911 NAUT-4 boulder, (C) Panoramic view of the penultimate glaciation moraine next to the last 912 glaciation moraine.

913 Figure 4. Geomorphological sketch of the two moraines existing in the lower part of the

914 Naute valley, together with the location of the CRE Sampling Boulder (CSB).

915 Figure 5. Geomorphological map of the Veleta cirque and sample location. We show CRE 916 ages from this work (SN samples) together with those from Palacios et al. (2016).

917 Figure 6. (A) Schematic transect of the Veleta cirque including the different landforms

918 existing across the cirque floor, and (B) Sketch showing the geomorphological approach used 919 in the selection of samples in the Veleta cirque.

920 Figure 7. (A) Photograph of Corral of the Veleta cirque from the West in September, 2016.

921 (B) Drawing according to the vision of Bide (1893), where the glacier seems still to cover its 922 maximum extension in $19^{\text {th }}$ century.

923 Figure 8. (A) Veleta cirque with its $19^{\text {th }}$ century moraine (source: Google Earth), (B) Vertical 924 view of the Veleta cirque floor from the Veleta peak, (C) Sampled boulder for SN-11-2, and 925 (D) Sampled boulder for SN-11-3. 
926 Figure 9. Sketch representing the erosion processes affecting a moraine: (A) Intense mass

927 movements and erosion reshaping the main ridge during the paraglacial stage, (B)

928 Stabilization phase of a moraine at the end of paraglacial phase, and (C) Mature stage of an

929 old moraine after a long period of erosion.

930 Table captions

931 Table 1. Current knowledge of Quaternary glacial stages in Sierra Nevada.

932 Table 2. Field data and characteristics of sampled boulders dated with ${ }^{10} \mathrm{Be}$ in Sierra Nevada

933 (*boulders are covered by snow thickness of 30 to $130 \mathrm{~cm}$ during 8 months per year). See text

934 for details.

935 Table 3. Analytical data and ${ }^{10} \mathrm{Be}$ sample exposure ages. 
Table 1. Current knowledge of Quaternary glacial stages in Sierra Nevada.

\section{Stage}

Chronology

\section{Processes and landforms}

Pre-Last Glaciation

Unknown

Last Glaciation

(Maximum Ice

Extent; MIE)

Deglaciation Two glacial advances during the Oldest

$$
\text { Dryas (YD) at ca. 13-12 ka }
$$

Glacial retreat until the Early Holocene at

$$
\text { ca. 10-9 ka }
$$

Holocene

Three stages with formation of glaciers occurred during the Late Holocene at ca. 2.8-2.7, 1.4-1.2 ka cal BP and LIA

From 1440 to 1710 AD a glacier existed in the Mulhacén cirque, and another glacier developed in the Corral de Veleta cirque until the mid- $20^{\text {th }}$ century
Possible existence of eroded moraines from glaciations occurred before the Last Glaciation as well as glacio-fluvial sediments distributed at lower elevations than moraines formed during the Last Glaciation (Hempel, 1960; Messerli, 1965; Lhenaff, 1977; Sánchez-Gómez, 1990).

Development of alpine valleys at elevations between 2000 and $2500 \mathrm{~m}$ in northern and southern slopes, respectively (Gómez-Ortiz et al., 2012, 2013, 2015; Oliva et al., 2014; Palacios et al., 2016).

The glaciated environment during the MIE encompassed $105 \mathrm{~km}^{2}$ (Palma et al., 2017).

Glacial retreat at ca. 19 ka followed by two phases of glacial development until the Holocene, mainly in the highest valleys from the northern slope of the massif (Gómez-Ortiz et al., 2012, 2013; Oliva et al., 2012, 2014; Palacios et al., 2016).

The glaciers formed during the YD finally melted and paraglacial activity favoured the development of rock glaciers in these areas (Gómez-Ortiz et al., 2012, 2013; Oliva et al., 2016b; Palacios et al.,

$$
\text { 2016). }
$$

Lake sediments suggest the development of a small glacier in the Mulhacén cirque, which is reflected in several moraine ridges distributed across the cirque floor (Oliva and Gómez-Ortiz, 2012; Oliva et

$$
\text { al., 2016a). }
$$

In the highest northern cirques between Mulhacén and Veleta peaks, historical sources and geomorphic evidence (i.e. moraines) shows evidence of the existence of several small glaciers that gradually disappeared during the $19^{\text {th }}$ and $20^{\text {th }}$ centuries (Gómez-Ortiz et al., 2001, 2009, 2018; Oliva and Gómez-Ortiz, 2012; Oliva et al., 2018a). 
Table 2. Field data and characteristics of sampled boulders dated with ${ }^{10} \mathrm{Be}$ in Sierra Nevada (*boulders are covered by snow thickness of 30 to $130 \mathrm{~cm}$ during 8 months per year). See text for details.

\begin{tabular}{lcccccc}
\hline Sample & $\begin{array}{c}\text { Latitude } \\
\left({ }^{(} \mathbf{N}\right)\end{array}$ & $\begin{array}{c}\text { Longitude } \\
\left({ }^{\circ} \mathbf{W}\right)\end{array}$ & $\begin{array}{c}\text { Elevation } \\
(\mathbf{m} \text { a.s.l. })\end{array}$ & $\begin{array}{c}\text { Thickness } \\
(\mathbf{c m})\end{array}$ & $\begin{array}{c}\text { Topographic } \\
\text { shielding } \\
\text { factor }\end{array}$ & $\begin{array}{c}\text { Snow shielding } \\
\text { factor }\end{array}$ \\
\hline NAUT-1 & 37.0196111 & 3.33047222 & 2164 & 1.5 & 0.97832 & \\
NAUT-2 & 37.0201111 & 3.33036111 & 2179 & 1.5 & 0.98414 & \\
NAUT-3 & 37.0212500 & 3.32977778 & 2211 & 1.5 & 0.98221 & \\
NAUT-4 & 37.0225556 & 3.32866667 & 2263 & 3.0 & 0.97817 & \\
*SN-11-1 & 37.0595833 & 3.36569444 & 3076 & 2.5 & 0.80979 & 0.70067 \\
*SN-11-2 & 37.0605833 & 3.36747222 & 3061 & 2.0 & 0.80979 & 0.70067 \\
*SN-11-3 & 37.0606944 & 3.36897222 & 3095 & 2.0 & 0.80979 & 0.70067 \\
\hline
\end{tabular}


Table 3. Analytical data and ${ }^{10} \mathrm{Be}$ sample exposure ages

\begin{tabular}{|c|c|c|c|c|c|c|c|c|}
\hline Sample & $\begin{array}{l}\text { Quartz } \\
\text { (g) }\end{array}$ & $\begin{array}{c}\begin{array}{c}{ }^{9} \mathrm{Be} \\
\text { carrier } \\
\text { solution } \\
(\mathbf{m g})^{\mathrm{a}}\end{array} \\
\end{array}$ & $\begin{array}{l}{ }^{10} \mathrm{Be} /{ }^{1} \mathrm{Be} \\
\left(\mathbf{x 1 0}^{13}\right)^{b}\end{array}$ & $\begin{array}{c}{\left[{ }^{10} \mathrm{Be}\right]} \\
\left(\mathrm{x10}^{3} \text { at.g }^{-1}\right)\end{array}$ & $\begin{array}{c}{ }^{10} \text { Be age } \\
\left(\text { CREp }^{\mathrm{c}}\right)(\mathrm{ka})\end{array}$ & $\begin{array}{c}{ }^{10} \text { Be age } \\
\left(\mathbf{C}-\mathbf{E}^{\mathrm{d}}\right) \\
(\mathbf{k a})\end{array}$ & $\begin{array}{c}{ }^{10} \text { Be age } \\
\left(\text { CREp }{ }^{c}\right)(\mathrm{ka}) \\
\text { With snow shielding } \\
\text { factor } \\
\end{array}$ & $\begin{array}{c}{ }^{10} \text { Be age } \\
\left(C_{-}{ }^{d}\right)(k a) \\
\text { With snow shielding } \\
\text { factor } \\
\end{array}$ \\
\hline NAUT-1 & 18.32 & 98.9 & $23.3 \pm 1.0$ & $2530 \pm 110$ & $134.8 \pm 10(6.2)$ & $130.4 \pm 10(6.1)$ & & \\
\hline NAUT-2 & 21.98 & 100.2 & $11.2 \pm 0.58$ & $1030 \pm 53$ & $53.7 \pm 4.3(2.9)$ & $54.5 \pm 4.3(2.9)$ & & \\
\hline NAUT-3 & 22.53 & 100.5 & $9.62 \pm 0.55$ & $868 \pm 50$ & $43.8 \pm 3.2(2.3)$ & $43.0 \pm 3.6(2.5)$ & & \\
\hline NAUT-4 & 22.62 & 100.7 & $28.6 \pm 1.2$ & $2580 \pm 110$ & $129.2 \pm 8.9(5.4)$ & $125.4 \pm 9.4(5.5)$ & & \\
\hline SN-11-1 & 30.91 & 100.9 & $0.127 \pm 0.052$ & $8.4 \pm 3.5$ & $0.31 \pm 0.10(0.10)$ & $0.28 \pm 0.11(0.11)$ & $0.34 \pm 0.12(0.12)$ & $0.32 \pm 0.13(0.13)$ \\
\hline SN-11-2 & 32.79 & 100.7 & $0.285 \pm 0.086$ & $17.7 \pm 5.3$ & $0.60 \pm 0.22(0.21)$ & $0.59 \pm 0.20(0.18)$ & $0.72 \pm 0.28(0.27)$ & $0.71 \pm 0.22(0.22)$ \\
\hline SN-11-3 & 31.39 & 101.0 & $0.159 \pm 0.050$ & $10.3 \pm 3.3$ & $0.36 \pm 0.09(0.09)$ & $0.35 \pm 0.11(0.10)$ & $0.40 \pm 0.11(0.11)$ & $0.38 \pm 0.12(0.12)$ \\
\hline Blank & & 99.4 & $0.0450 \pm 0.013$ & & & & & \\
\hline
\end{tabular}

${ }^{\mathrm{a}}$ Carrier has a concentration of $3025 \mu \mathrm{g}{ }^{9} \mathrm{Be} / \mathrm{g}$.

${ }^{\circ} \mathrm{Sample}{ }^{10} \mathrm{Be} /{ }^{9} \mathrm{Be}$ ratios corrected for batch-specific analytical blank ratio of $(4.5 \pm 1.3) \times 10^{-15}$.

${ }^{110} \mathrm{Be}$ ages calculated with the online CREp exposure age calculator (Martin et al., 2017). 1sigma errors include analytical and production rate uncertainties; analytical errors shown in brackets.

${ }^{d}{ }^{10} \mathrm{Be}$ ages calculated with the online exposure age calculator formerly known as the CRONUS-Earth online exposure age calculator version 3 (Balco et al., 2008). 1sigma errors include analytical and production rate uncertainties; analytical errors shown in brackets. 
Figure (Color)

Click here to download high resolution image

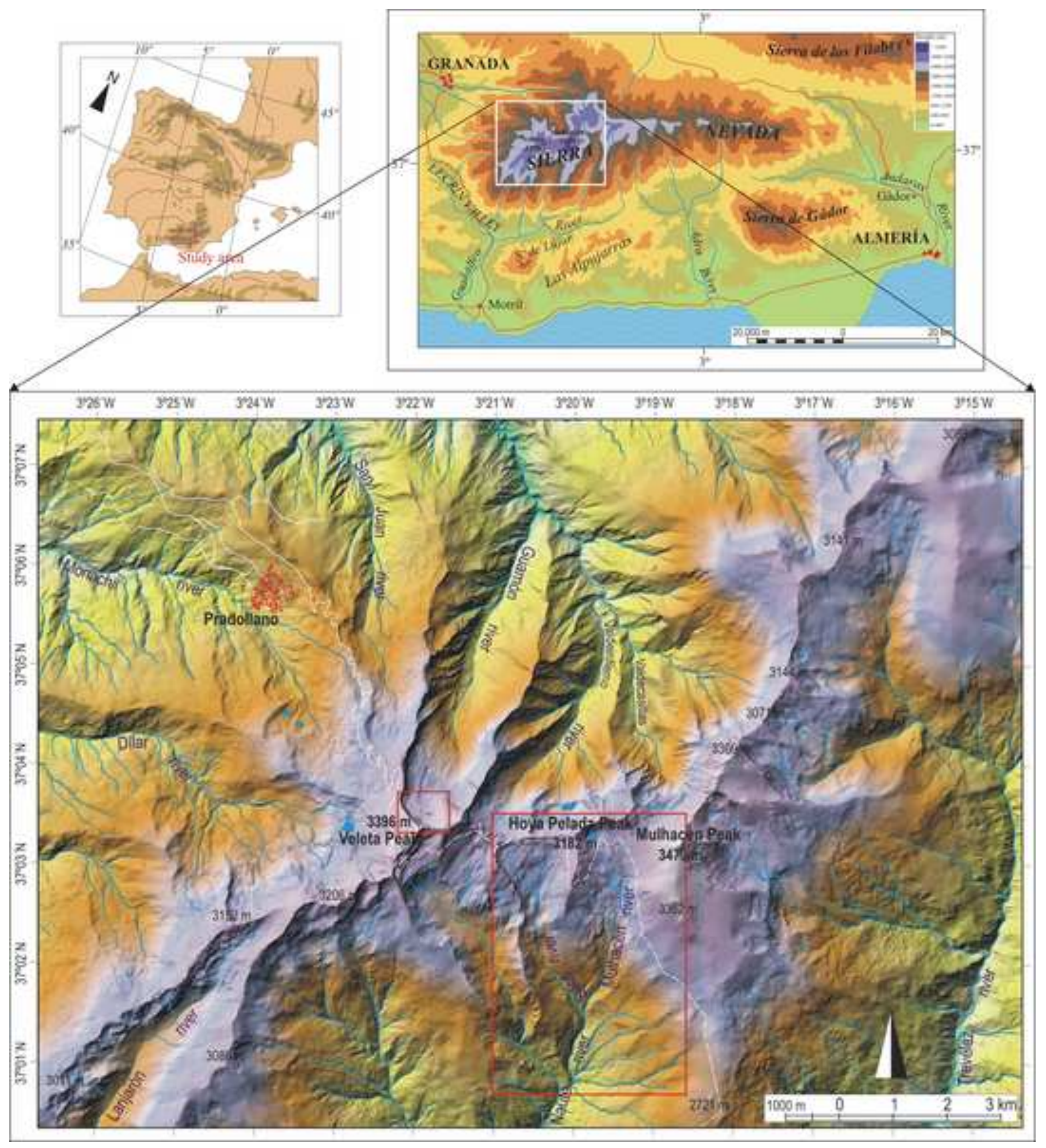




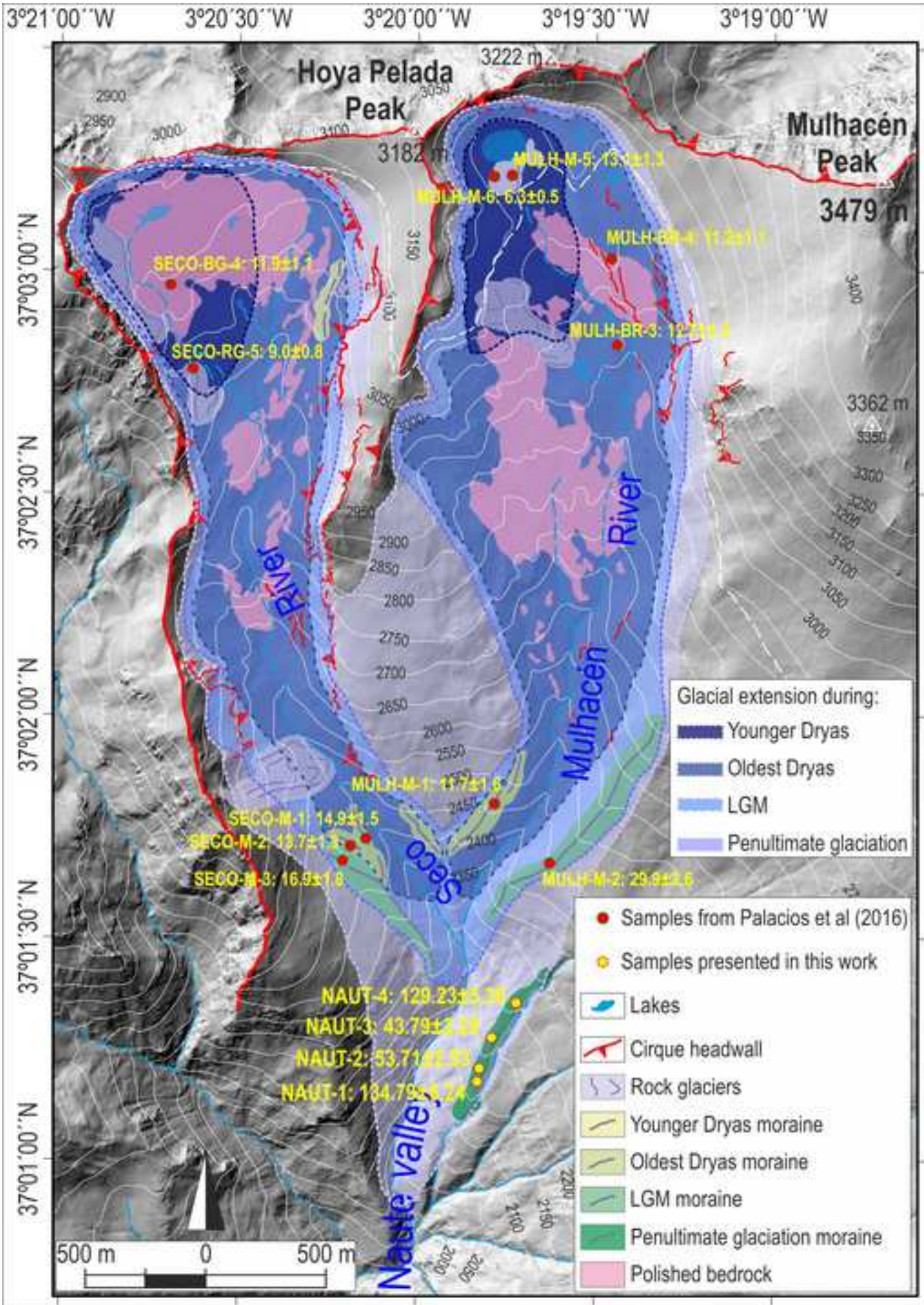


Figure (Color)
Click here to download high resolution image

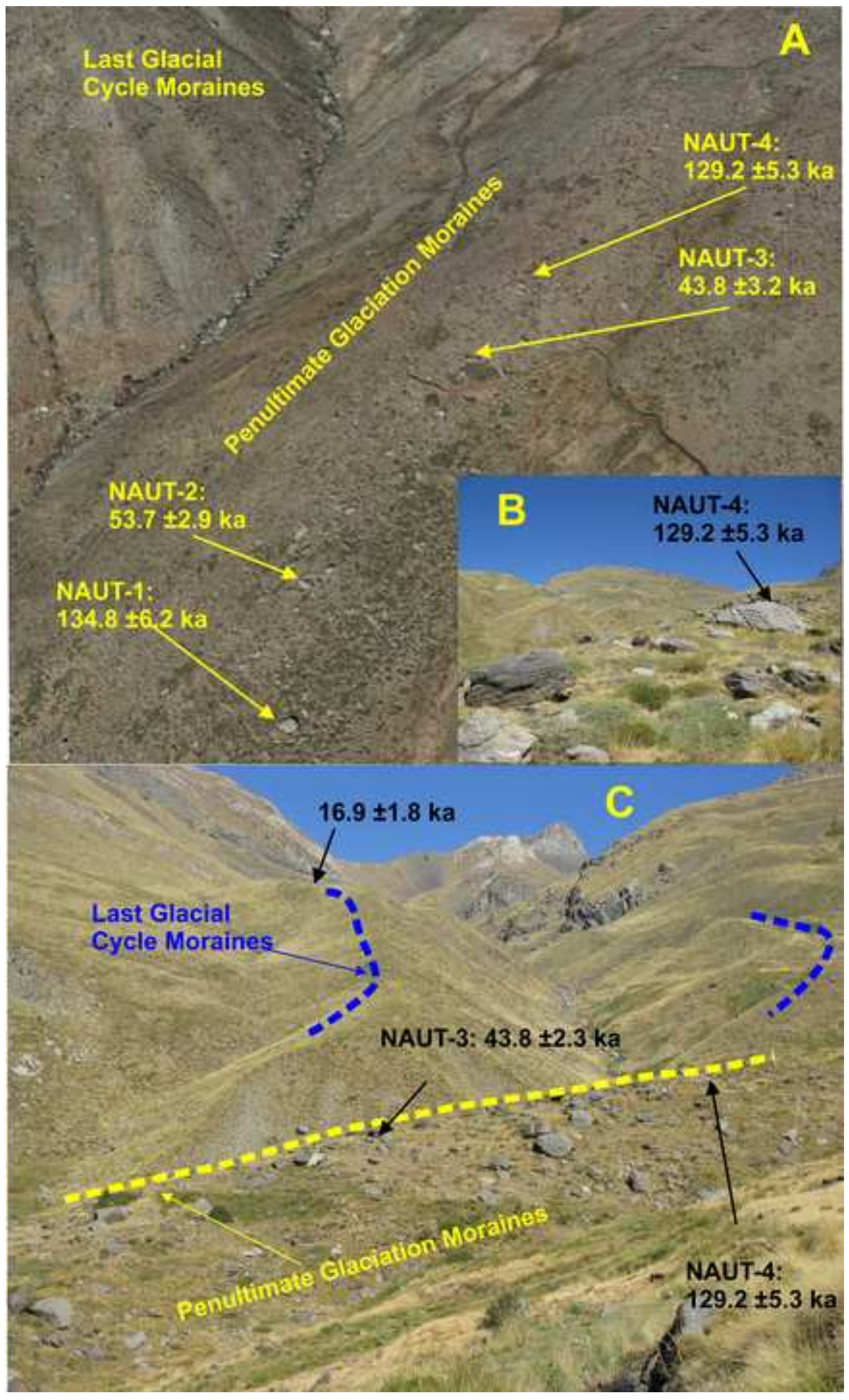

Last Glacial

$129.2 \pm 5.3 \mathrm{ka}$

NAUT-3:

$43.8 \pm 3.2 \mathrm{ka}$

NAUT-2:

$53.7 \pm 2.9 \mathrm{ka}$ 


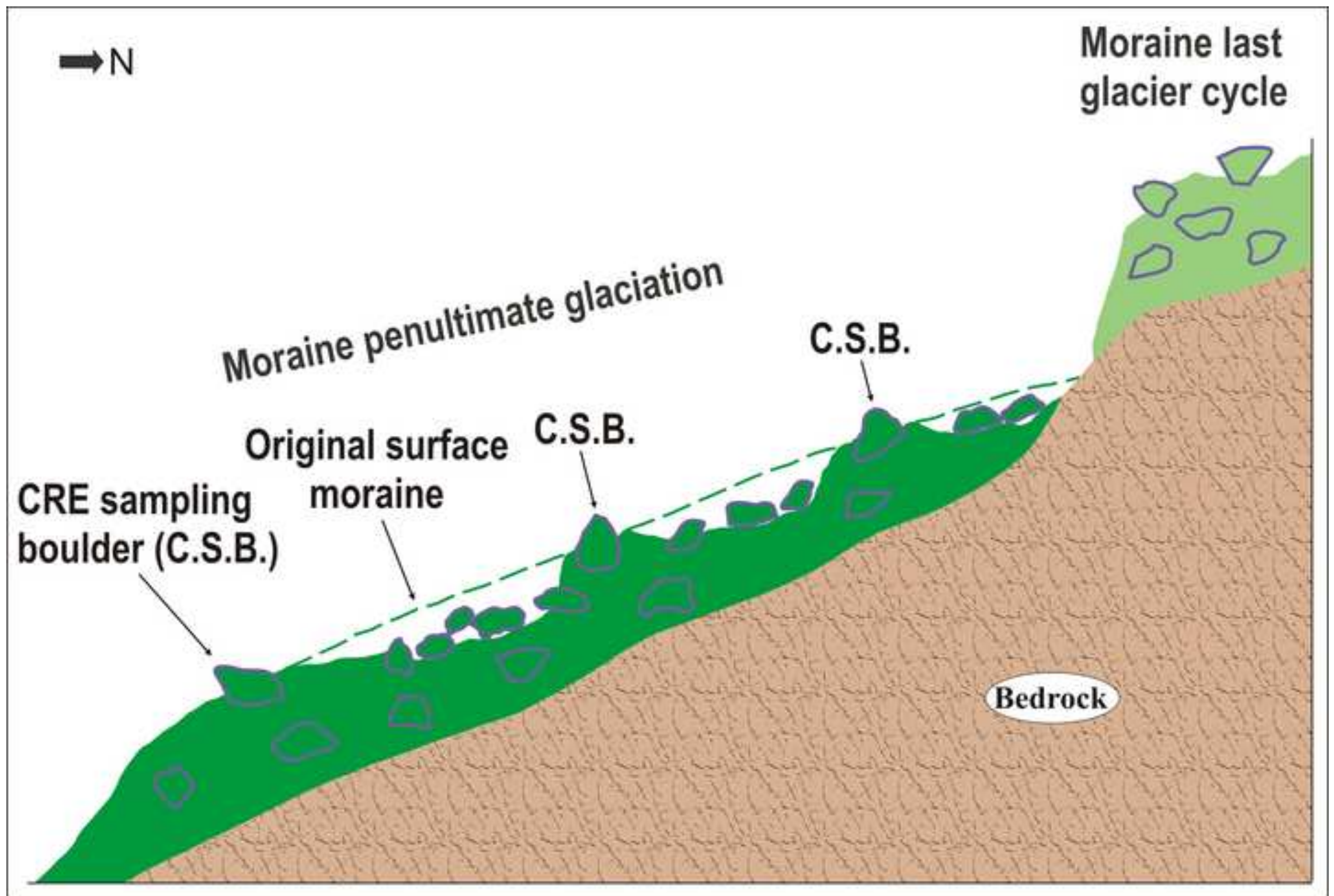


Click here to download high resolution image

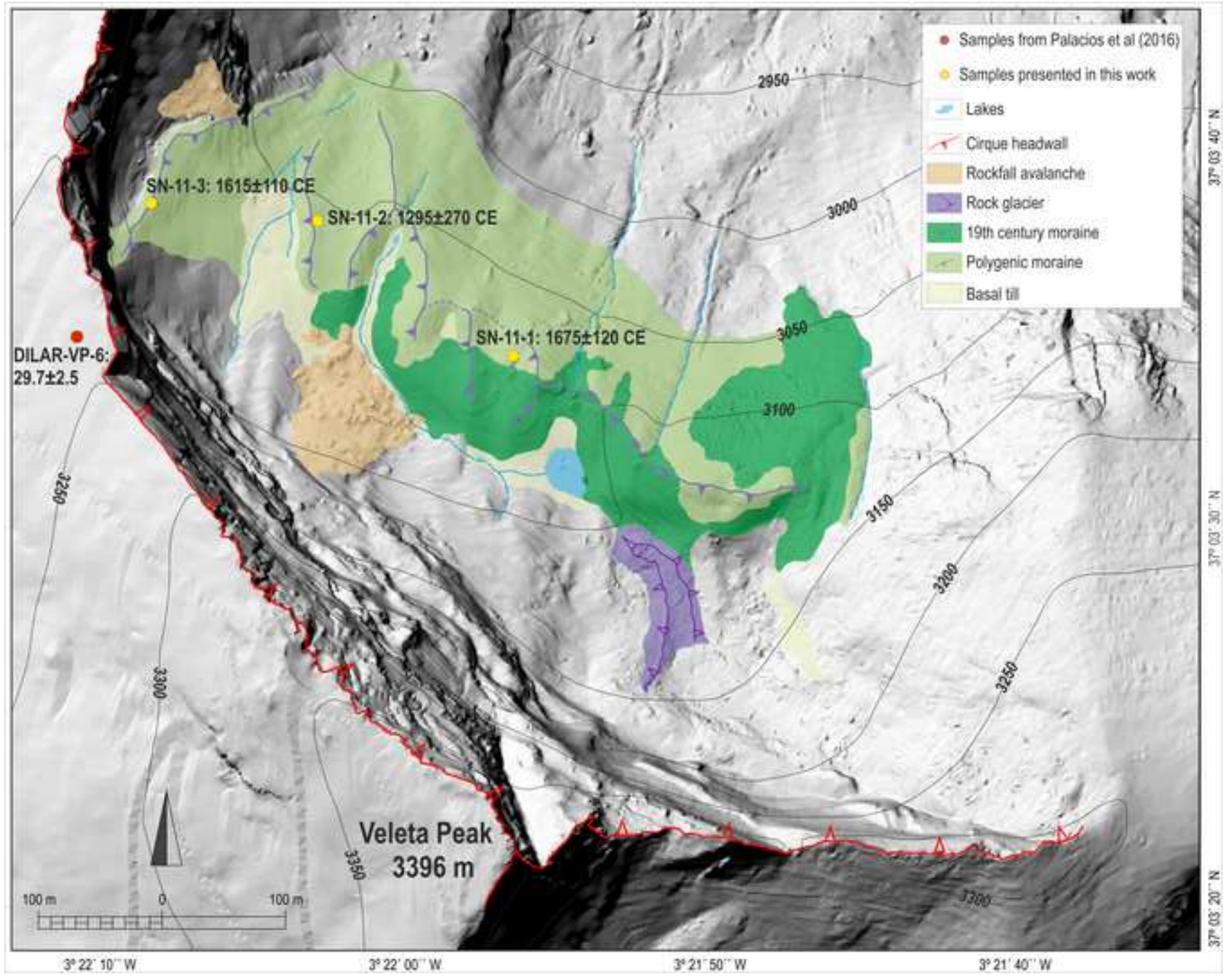




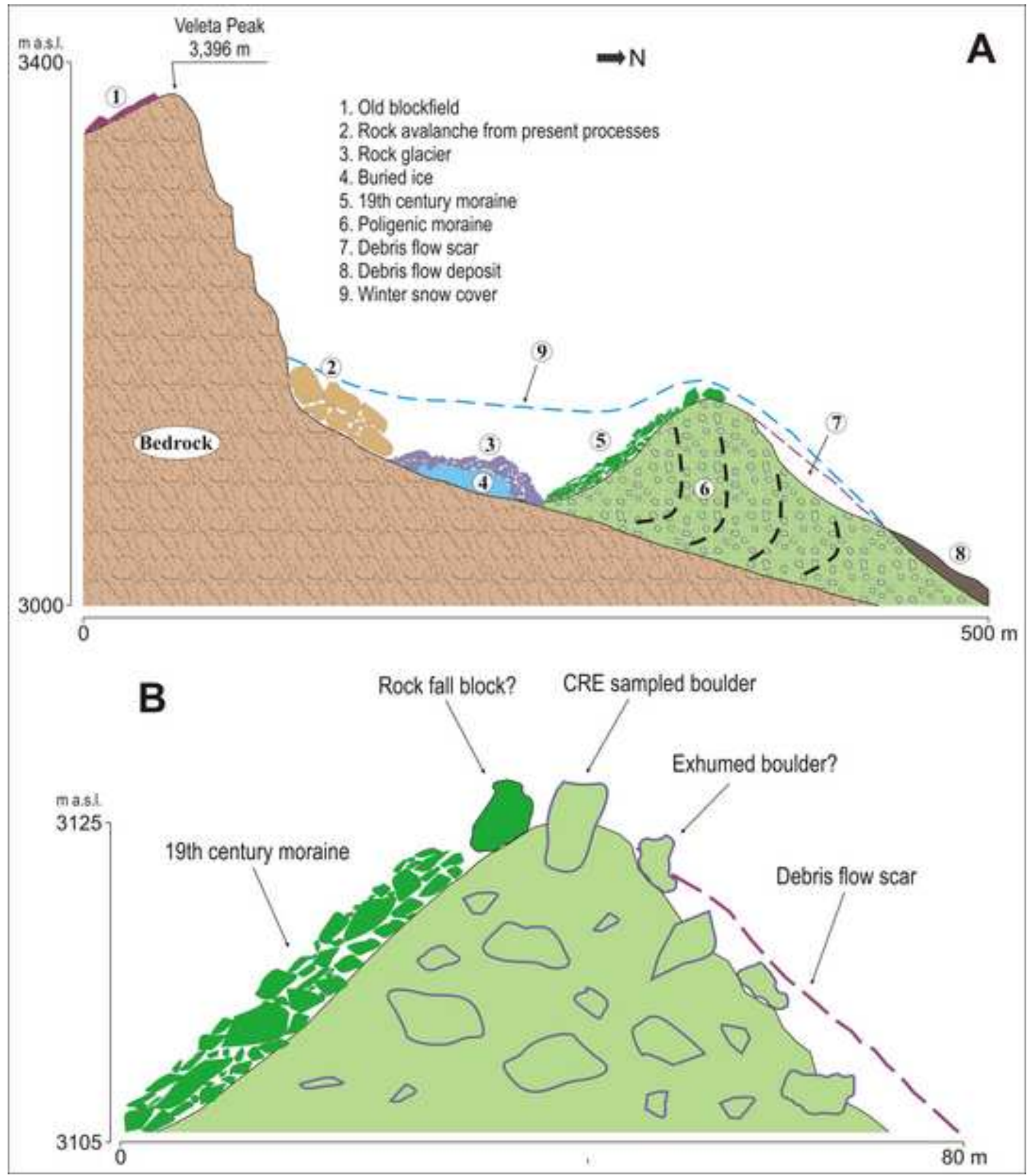


Figure (Color)

Click here to download high resolution image

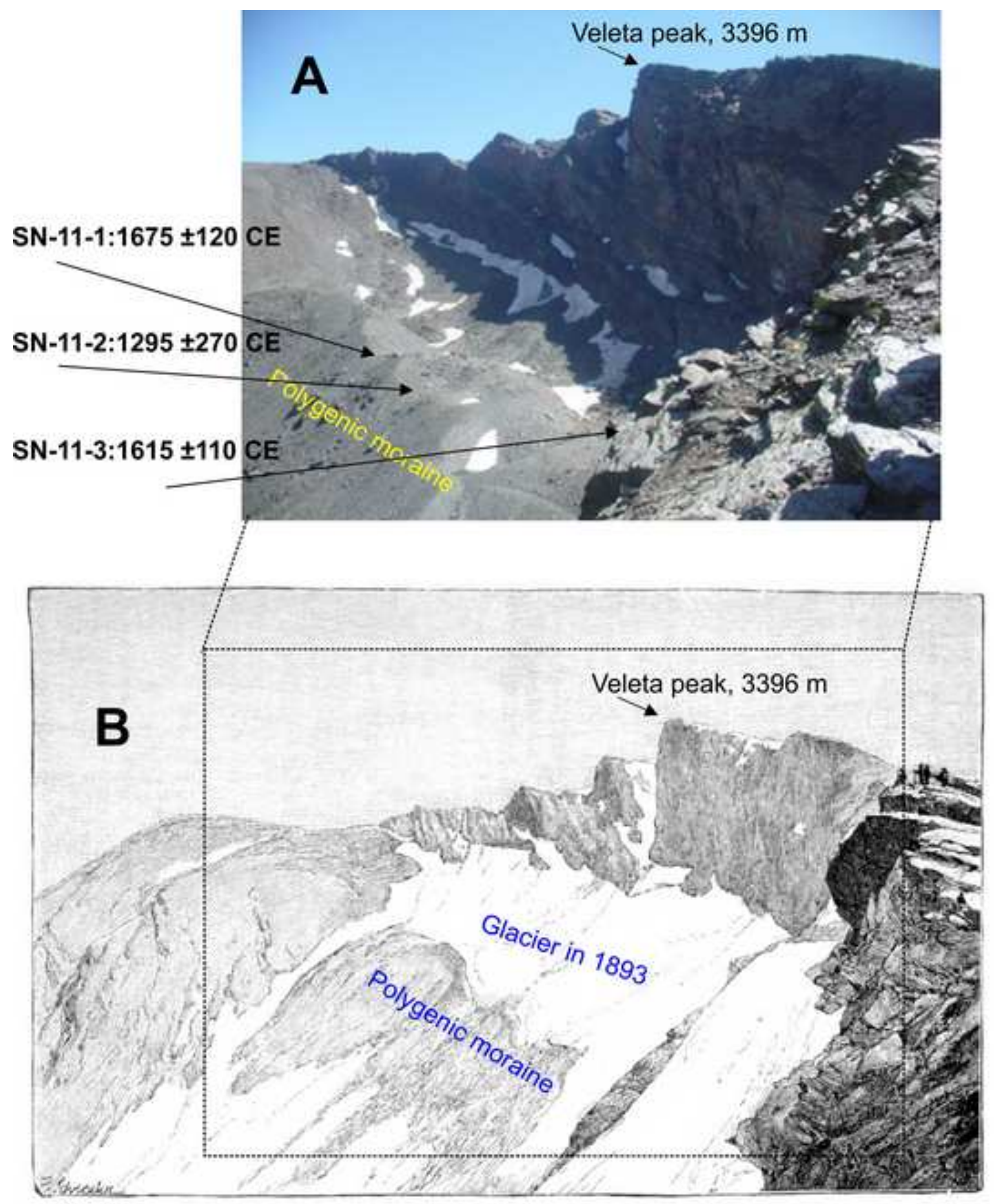




\section{Figure (Color)
Click here to download high resolution image}

SNG11-3: $1615 \pm 110 \mathrm{CE}$

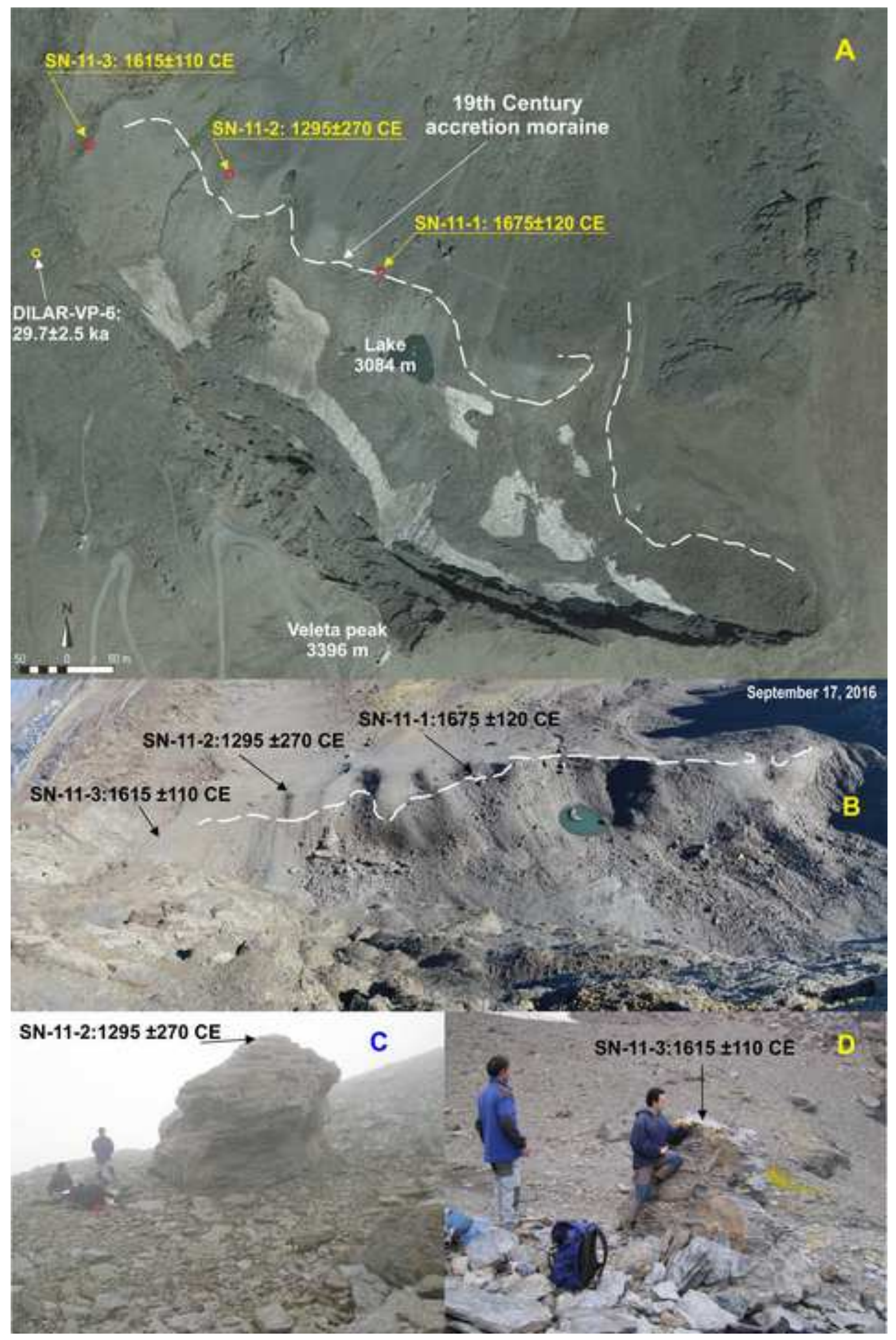




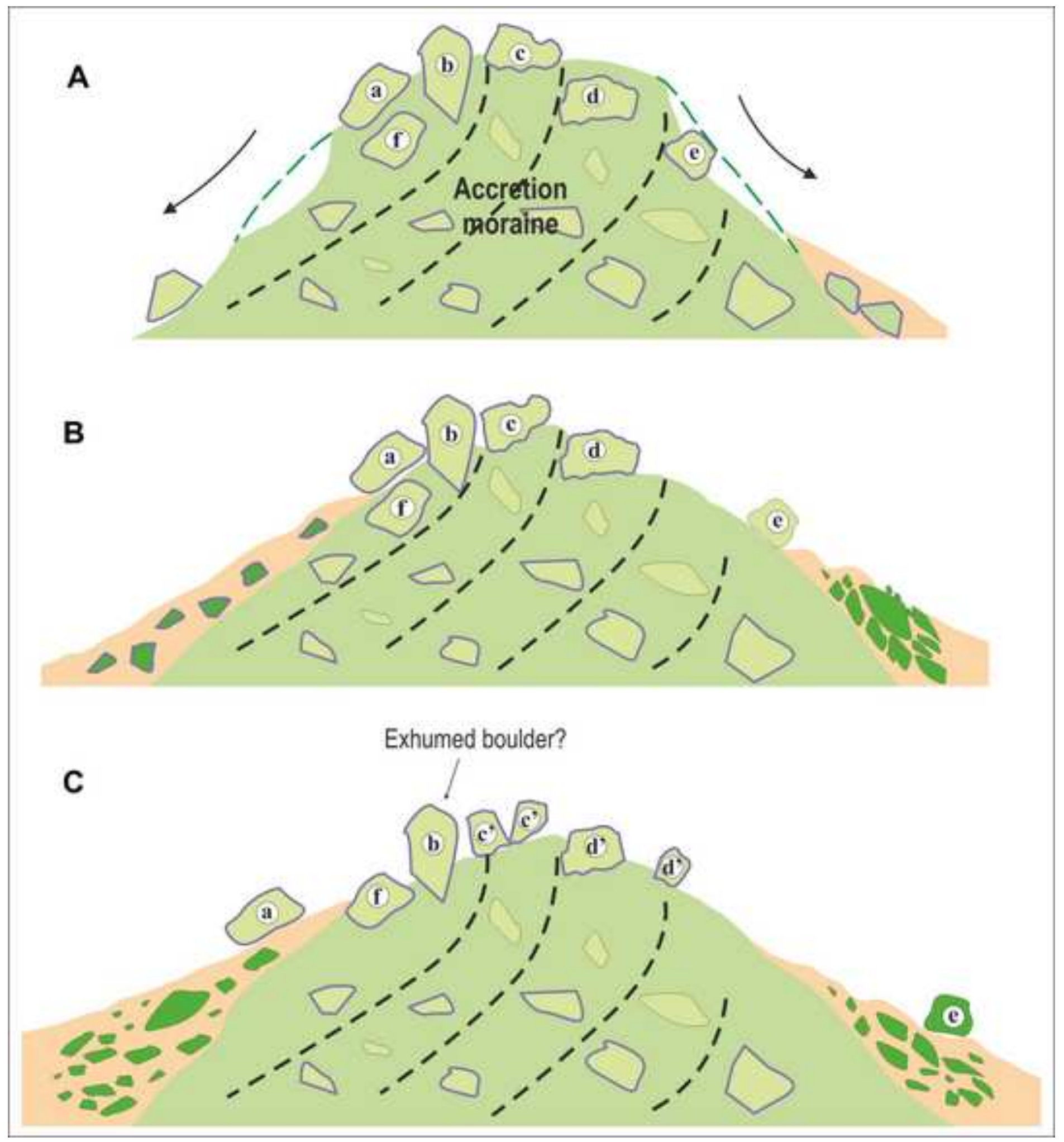


Click here to download high resolution image

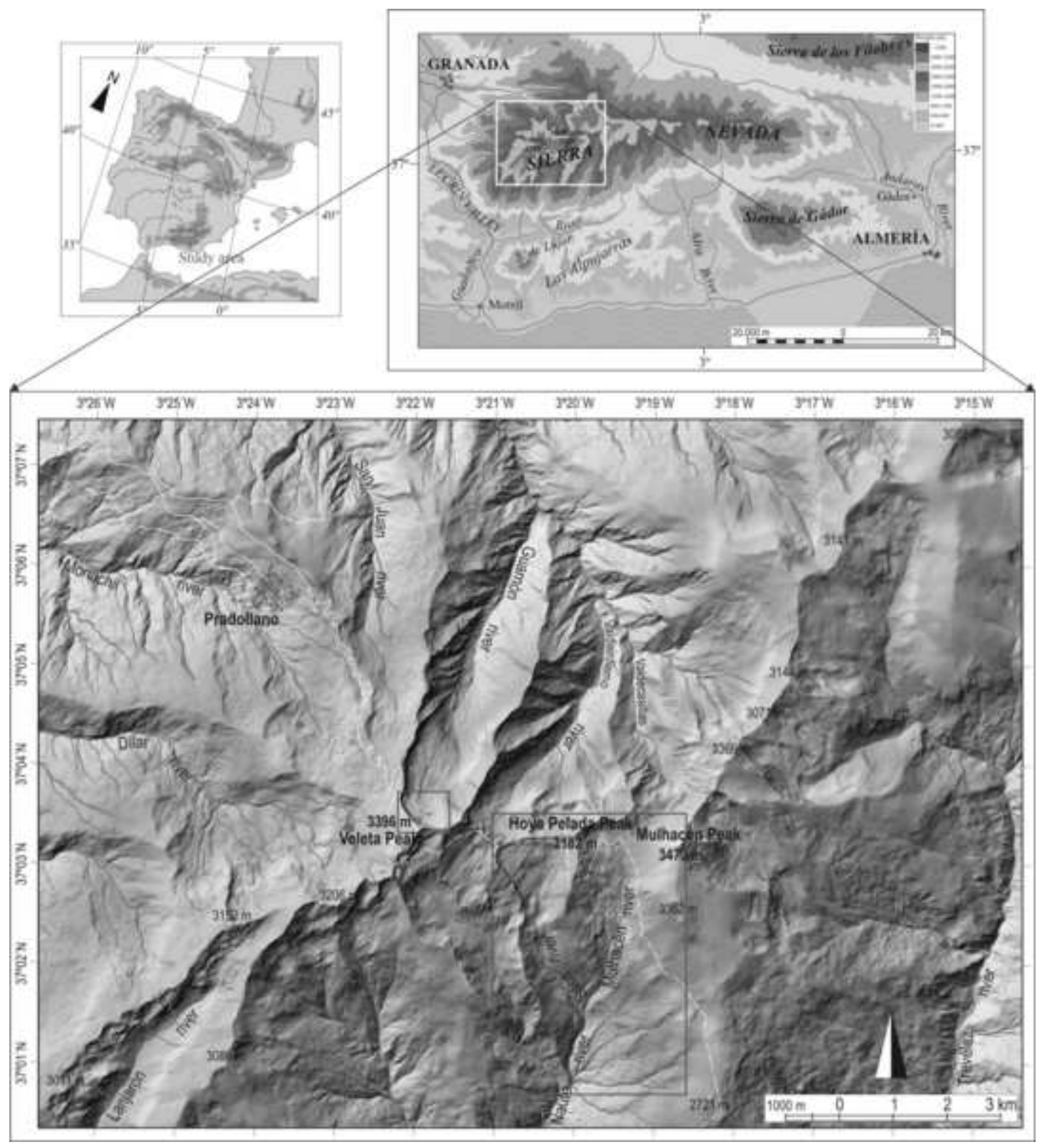




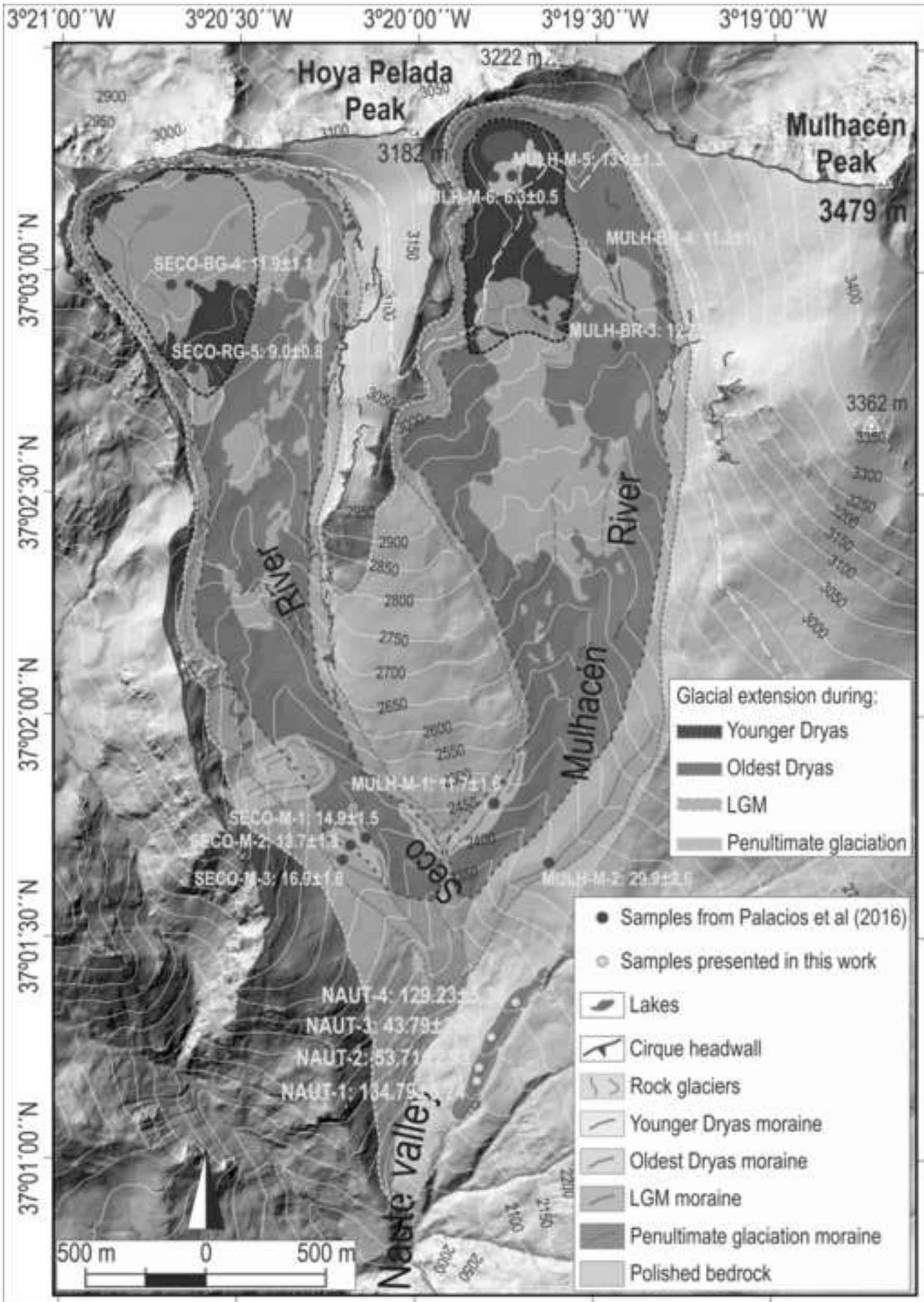




\section{Click here to download high resolution image}

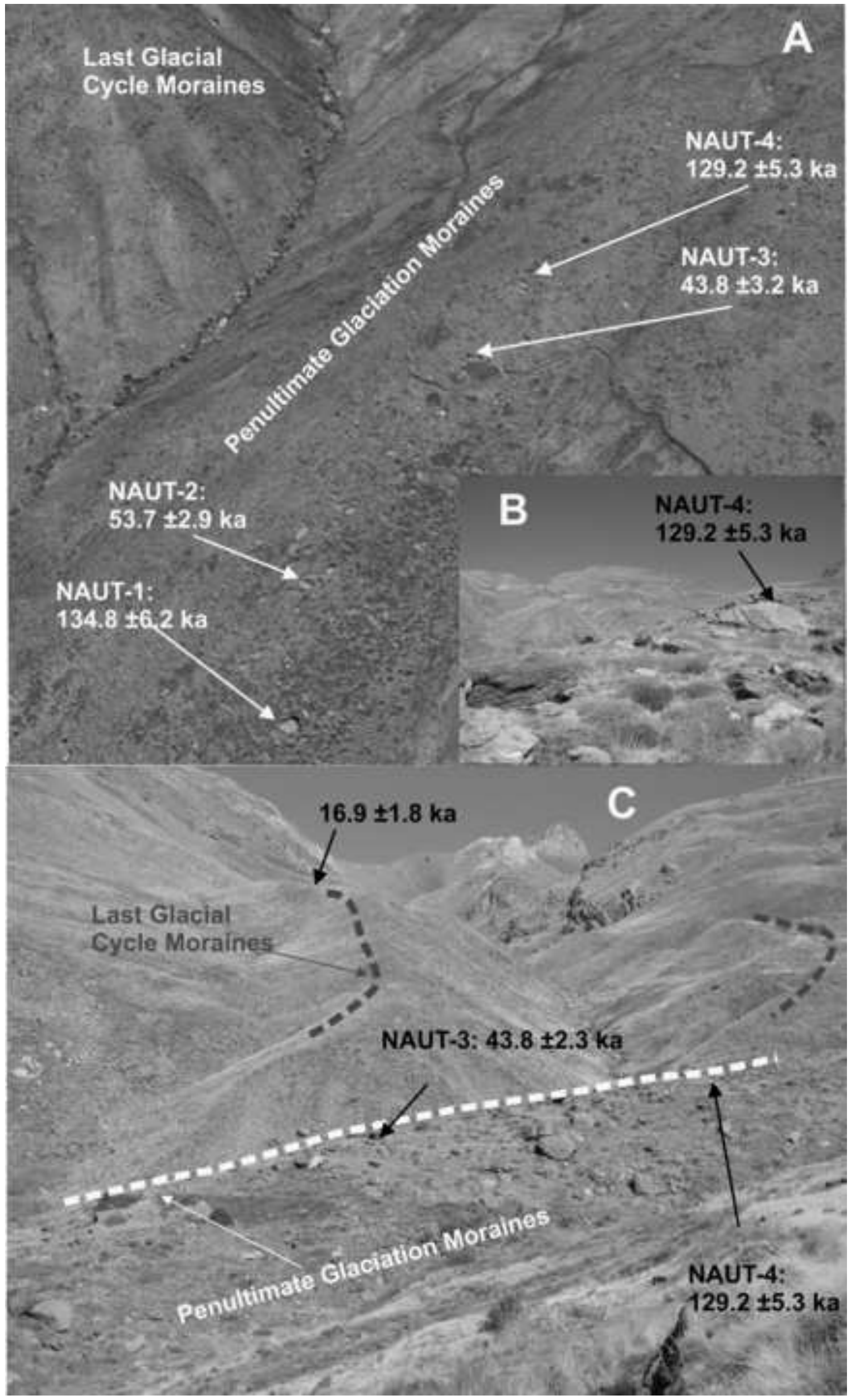




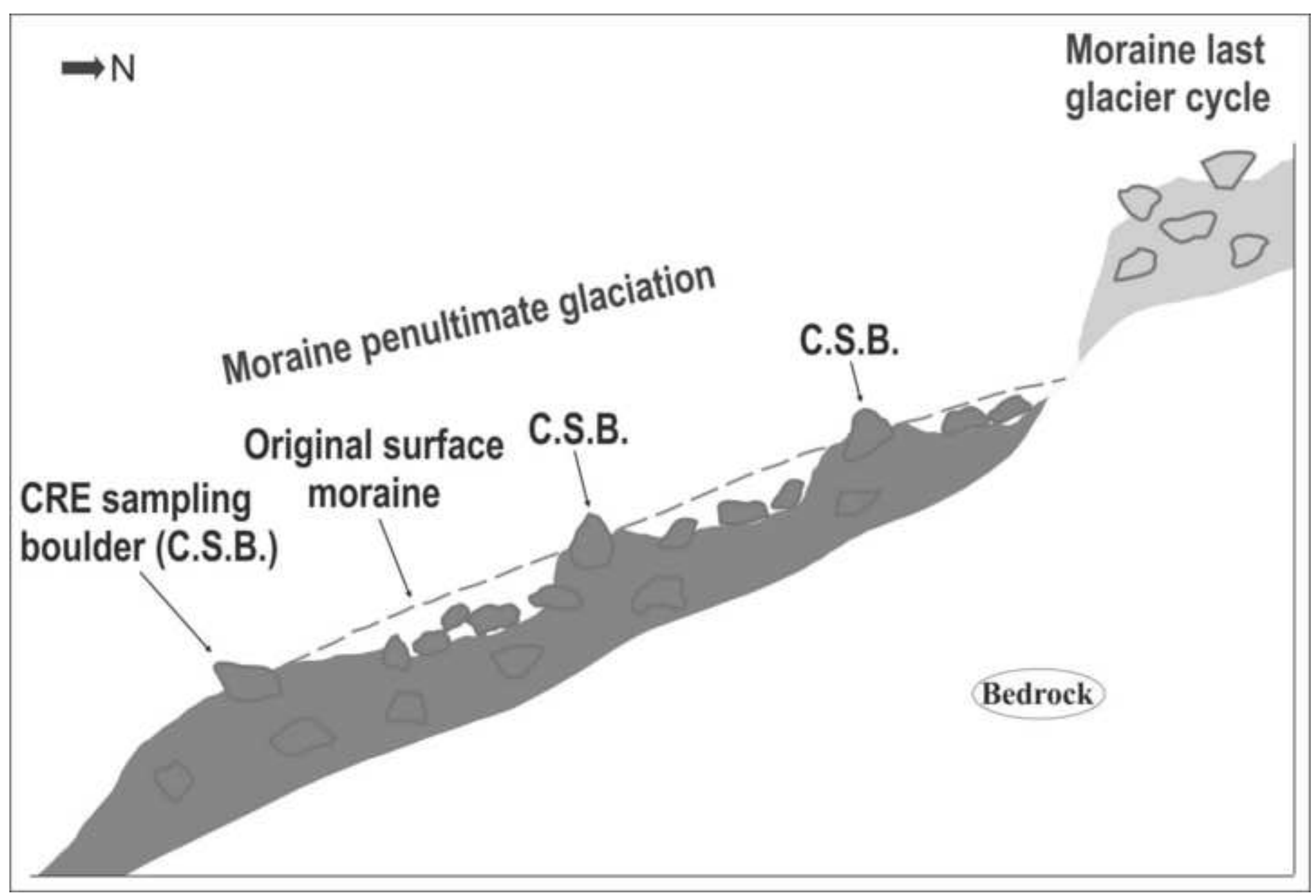


Figure (Greyscale)
Click here to download high resolution image

Figure (Greyscale)
Click here to download high resolution image

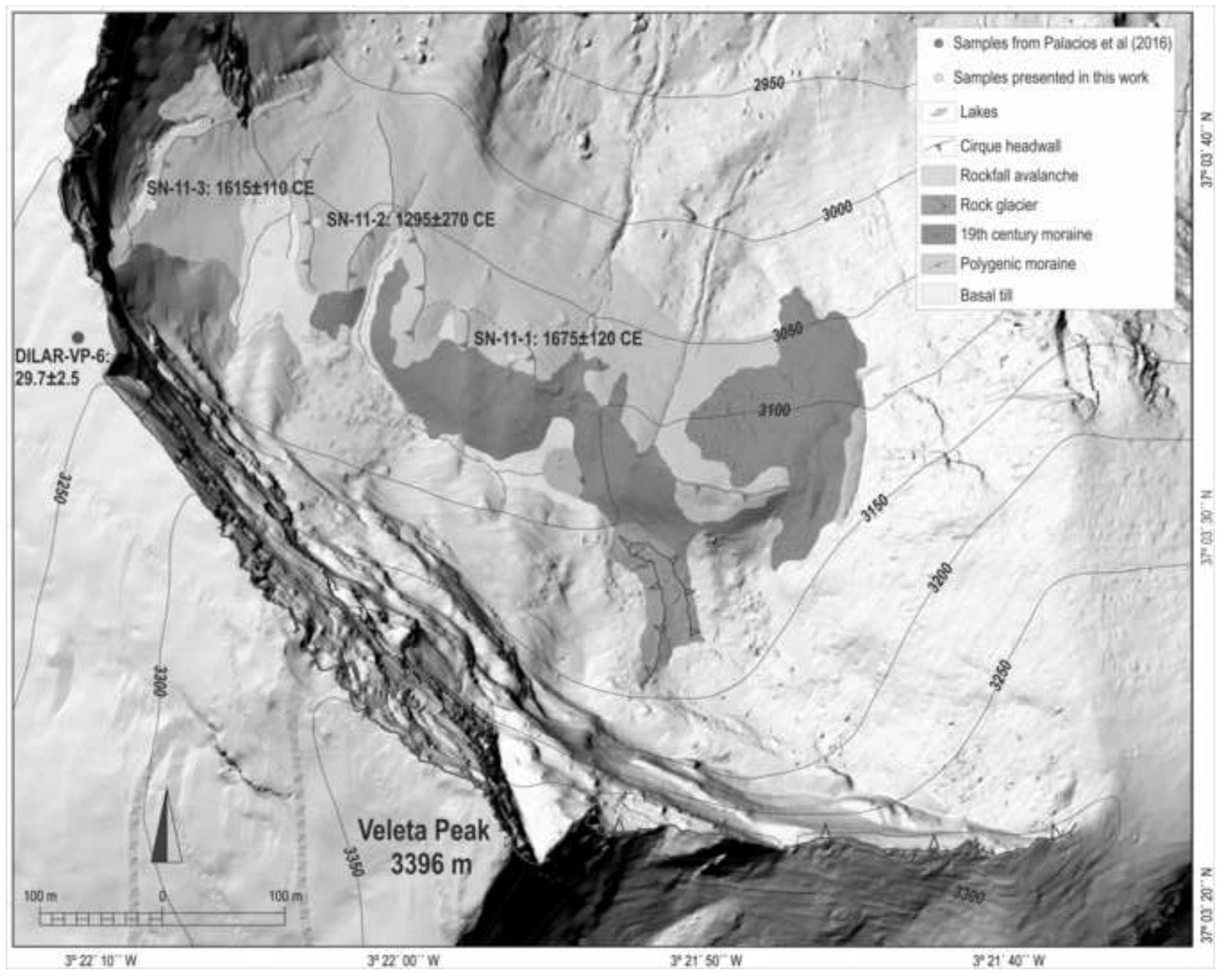

3

.


Figure (Greyscale)

Click here to download high resolution image

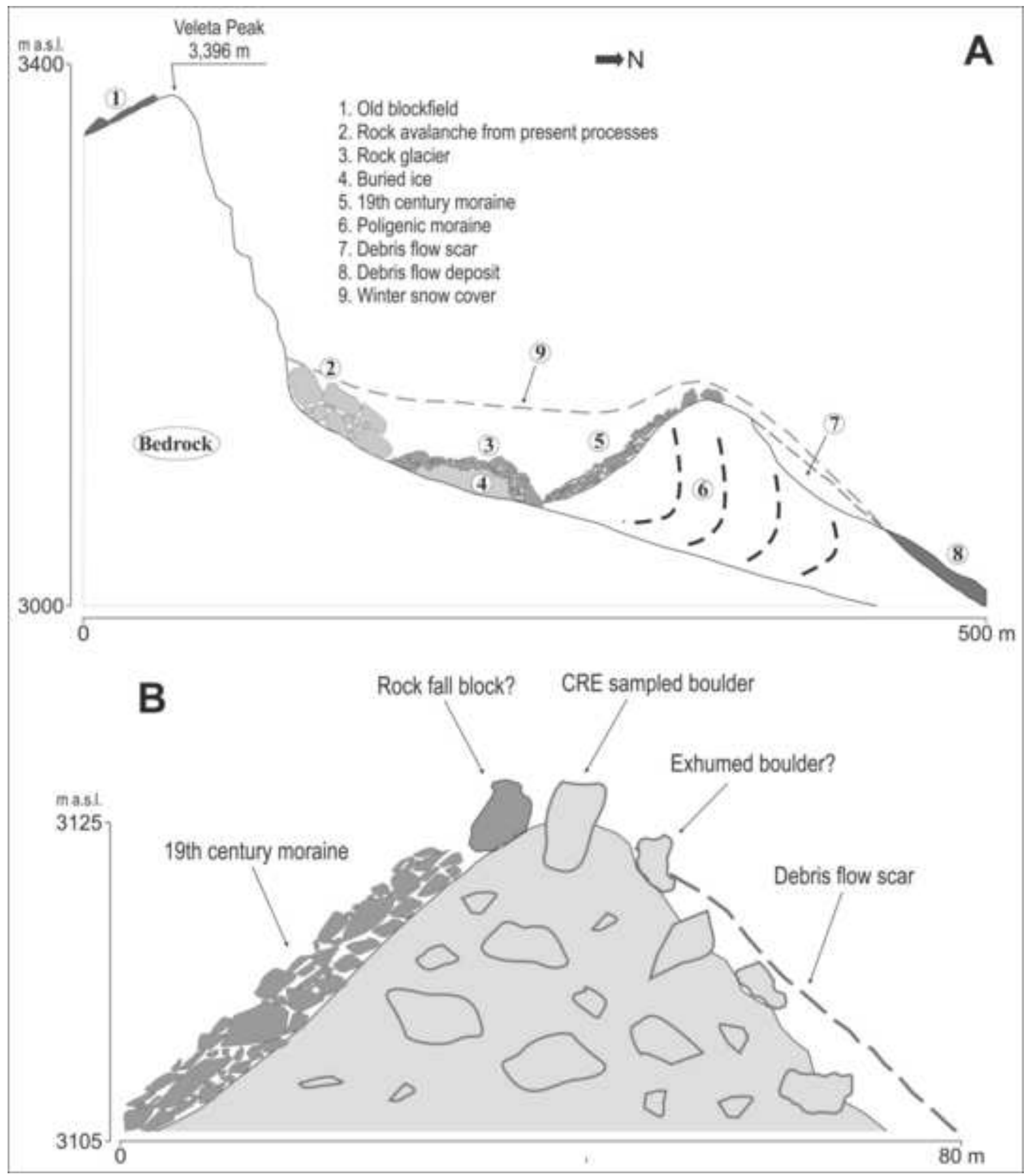

Rock aratenche

Rock avalanche from present processes

Buried ice

Poligenic moraine

Debris low scar

Debris flow deposit

(1) 
Figure (Greyscale)

Click here to download high resolution image

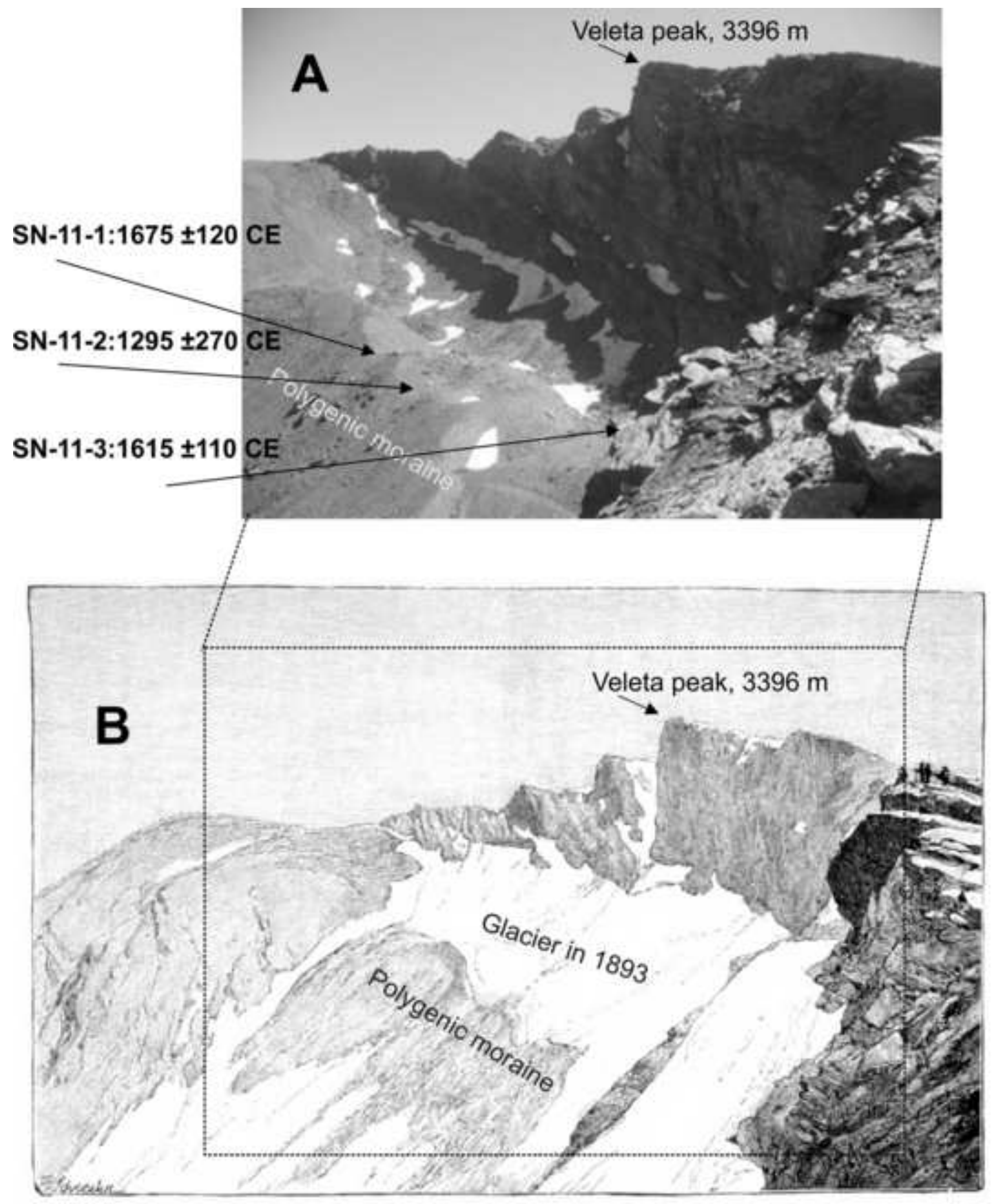




\section{Figure (Greyscale)
Click here to download high resolution image}

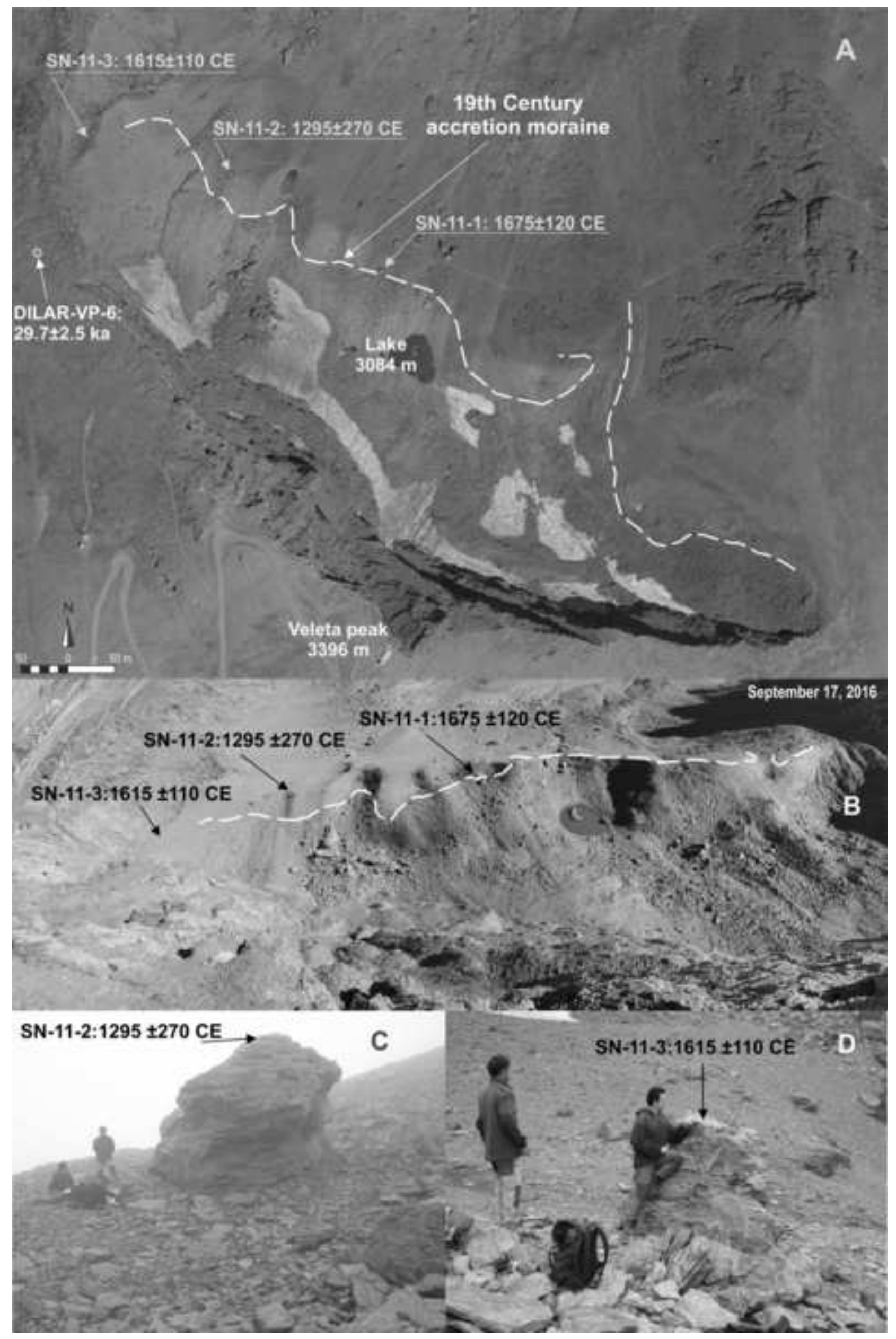

SN5113:161Sะ110 CE

19th Century 


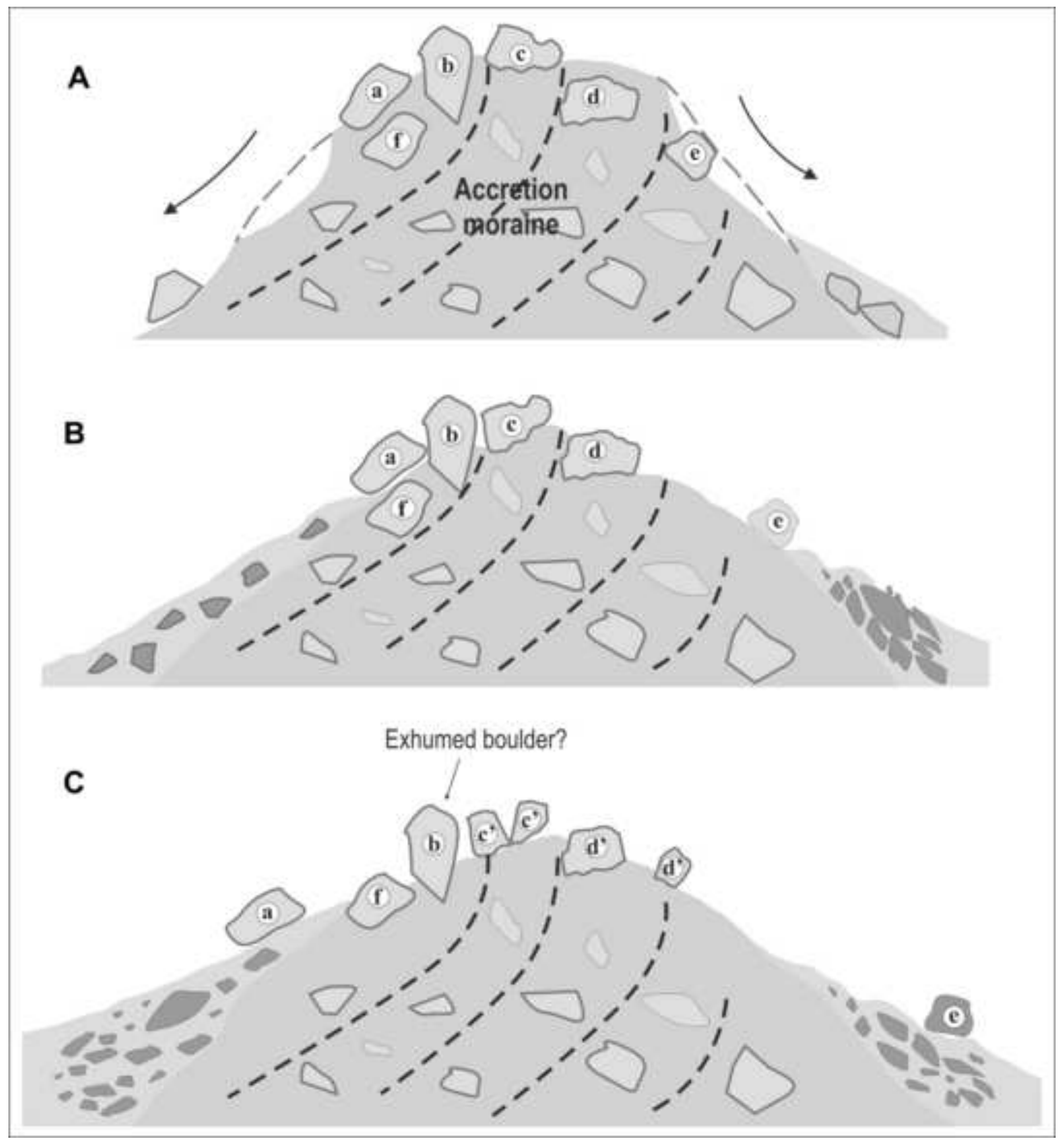


Click here to download Interactive Map file (.kml or .kmz): doc.kml 